\title{
The Current Status and Future Prospects of Oncolytic Viruses in Clinical Trials against Melanoma, Glioma, Pancreatic, and Breast Cancers
}

\author{
Ibrahim Ragab Eissa ${ }^{1,2,3,+}{ }^{\oplus}$, Itzel Bustos-Villalobos ${ }^{1,+}{ }^{,}$Toru Ichinose ${ }^{1}$, Shigeru Matsumura ${ }^{1}$, \\ Yoshinori Naoe ${ }^{1}$, Noriyuki Miyajima ${ }^{4}$, Daishi Morimoto ${ }^{2}$, Nobuaki Mukoyama ${ }^{5}$, \\ Wu Zhiwen ${ }^{1,2}$, Maki Tanaka ${ }^{6}$, Hitoki Hasegawa ${ }^{7}$, Seiji Sumigama ${ }^{7}{ }^{\circledR}$, Branko Aleksic ${ }^{7}$, \\ Yasuhiro Kodera ${ }^{2}$ and Hideki Kasuya ${ }^{1, *}$ \\ 1 Cancer Immune Therapy Research Center, Graduate School of Medicine, Nagoya University, \\ Nagoya 466-8550, Japan; brahimessa@med.nagoya-u.ac.jp (I.R.E.); bustositzel@med.nagoya-u.ac.jp (I.B.-V.); \\ t-ichinose@med.nagoya-u.ac.jp (T.I.); smatsumu@med.nagoya-u.ac.jp (S.M.); \\ ynaoe@med.nagoya-u.ac.jp (Y.N.); wu.zhiwen@med.nagoya-u.ac.jp (W.Z.) \\ 2 Department of Surgery II, Graduate School of Medicine, Nagoya University, Nagoya 466-8550, Japan; \\ d-morimoto@med.nagoya-u.ac.jp (D.M.); ykodera@med.nagoya-u.ac.jp (Y.K.) \\ 3 Faculty of Science, Tanta University, Tanta 31527, Egypt \\ 4 Department of Transplantation and Endocrine Surgery, Graduate School of Medicine, Nagoya University, \\ Nagoya 466-8550, Japan; miyajima@med.nagoya-u.ac.jp \\ 5 Department of Otolaryngology Graduate School of Medicine, Nagoya University, Nagoya 466-8550, Japan; \\ tamgpad7042@gmail.com \\ 6 Takara Bio Inc., Kusatsu, Shiga 525-0028, Japan; tanakamy@takara-bio.co.jp \\ 7 Office of International Affairs, Graduate School of Medicine, Nagoya University, Nagoya 466-8550, Japan; \\ hitoki@med.nagoya-u.ac.jp (H.H.); sumigama@med.nagoya-u.ac.jp (S.S.); branko@med.nagoya-u.ac.jp (B.A.) \\ * Correspondence: kasuya@med.nagoya-u.ac.jp; Tel.: +81-52-744-2507 \\ + These authors contributed equally to this work.
}

Received: 18 July 2018; Accepted: 11 September 2018; Published: 26 September 2018

\begin{abstract}
Oncolytic viral therapy has been accepted as a standard immunotherapy since talimogene laherparepvec (T-VEC, Imlygic ${ }^{\circledR}$ ) was approved by the Food and Drug Administration (FDA) and European Medicines Agency (EMA) for melanoma treatment in 2015. Various oncolytic viruses (OVs), such as HF10 (Canerpaturev-C-REV) and CVA21 (CAVATAK), are now actively being developed in phase II as monotherapies, or in combination with immune checkpoint inhibitors against melanoma. Moreover, in glioma, several OVs have clearly demonstrated both safety and a promising efficacy in the phase I clinical trials. Additionally, the safety of several OVs, such as pelareorep (Reolysin ${ }^{\circledR}$ ), proved their safety and efficacy in combination with paclitaxel in breast cancer patients, but the outcomes of OVs as monotherapy against breast cancer have not provided a clear therapeutic strategy for OVs. The clinical trials of OVs against pancreatic cancer have not yet demonstrated efficacy as either monotherapy or as part of combination therapy. However, there are several oncolytic viruses that have successfully proved their efficacy in different preclinical models. In this review, we mainly focused on the oncolytic viruses that transitioned into clinical trials against melanoma, glioma, pancreatic, and breast cancers. Hence, we described the current status and future prospects of OVs clinical trials against melanoma, glioma, pancreatic, and breast cancers.
\end{abstract}

Keywords: oncolytic viruses; clinical trials; melanoma; glioma; pancreatic; breast cancer clinical trials 


\section{Historical Snapshots}

It may come as a surprise that the treatment of cancer by using viruses was not the result of extraordinary experiments or clear-sighted theories. On the contrary, it stemmed from an observation by Dr. George Dock. In 1904, Dock reported the case of a patient with leukemia, whose leukocyte count decreased from 367,070 to 7500 over a period of two weeks, after an attack of what was presumed to be influenza [1]. Following this report, Levaditi noticed the growth and unusually long survival of the viruses in the vaccines administered to mice and rats with neoplasms [2]. Levaditi's observations were confirmed by Rivers and Pearce, who concluded that the virus vaccine multiplied in a transplantable rabbit tumor of epithelial origin [3]. Throughout the 1920s and into the 1940s, viral biology was poorly understood, and there were few laboratory-based studies on viruses to investigate these previous observations. In addition, oncolytic viruses (OVs) were not studied in detail, because earlier works focused on virus growth in tumors, rather than studying the effects of these viruses on tumor growth [4]. In 1940, past observations inspired Pack to perform the first clinical trial in this field, in which an attenuated virus against melanoma led to a remarkable partial remission [5]. Subsequently, in 1949, another study showed an improvement in seven of 13 patients with Hodgkin's Syndrome IX, who had progression of viral hepatitis for more than a month [6]. By the end of the 1940s and into the early 1950s, ex vivo virus cultivation was performed [7], which provided a better understanding of the proliferative capacity of cancer and normal cells [8].

In parallel with the advent of cell culture and viral manipulation, the concept of OVs was addressed by Moore in 1949, whose first known preclinical study in this field evaluated the ability of the Russian Far East Virus to inhibit the growth of five transplanted mouse tumors [9]. Other studies emphasized the anti-tumor effect of the Russian encephalitis virus in chicken tumors and sarcoma 180 [10,11], and cervical carcinoma [12] and the Semliki Forest virus in rabbit fibromas [13]. The most important discovery of this era was by Lindenmann and Klein, who demonstrated that post-oncolytic immunity was the result of enhanced humoral immunity against tumor cell antigens, via the secretion of immunoglobulin and cytotoxic antibodies [14]. In the 1970s and 1980s, several studies investigated the effects of a number of viruses on tumor regression in various leukemia models [15-17], Hodgkins' disease $[18,19]$, and Burkitt's lymphoma associated with measles infection [20].

The revolution of recombinant DNA technology over the last 30 years made it possible to identify the essential genes for viral replication and the viral pathogenic mechanisms. The first studies to use genetically modified OVs were published in 1991 by Martuza et al. They developed herpes simplex virus (HSV) mutants (dlsptk) with depleted thymidine kinase or Infected cell protein (ICP) 34.5. These viruses were attenuated and demonstrated to be oncolytic, with selective replication in the diving cells of human glioma xenografts [21].

In the context of the recombinant DNA revolution, recent advances in viral cellular and genomic structure, as well as tumor development and immunology, have provided the main theme for using OVs as cancer therapy. In the last two decades, nine different families of viruses, including both DNA and RNA viruses, were successfully transitioned from preclinical studies into early randomized clinical-phase trials (Table 1). In this review, we will outline in detail the clinical trials of various OVs against melanoma, glioma, pancreatic, and breast cancers. In addition, we will discuss the progress of the clinical trial phases of each disease, and address the future of these trials. However, in this review, we selected the clinical trials that were completed and that reported the final results in the abstract or full paper for in four tumor types (melanoma, glioma, pancreatic, and breast cancer). There are other oncolytic viruses that proved their safety and efficacy in other tumor types. 
Table 1. Genetic modification of oncolytic viruses.

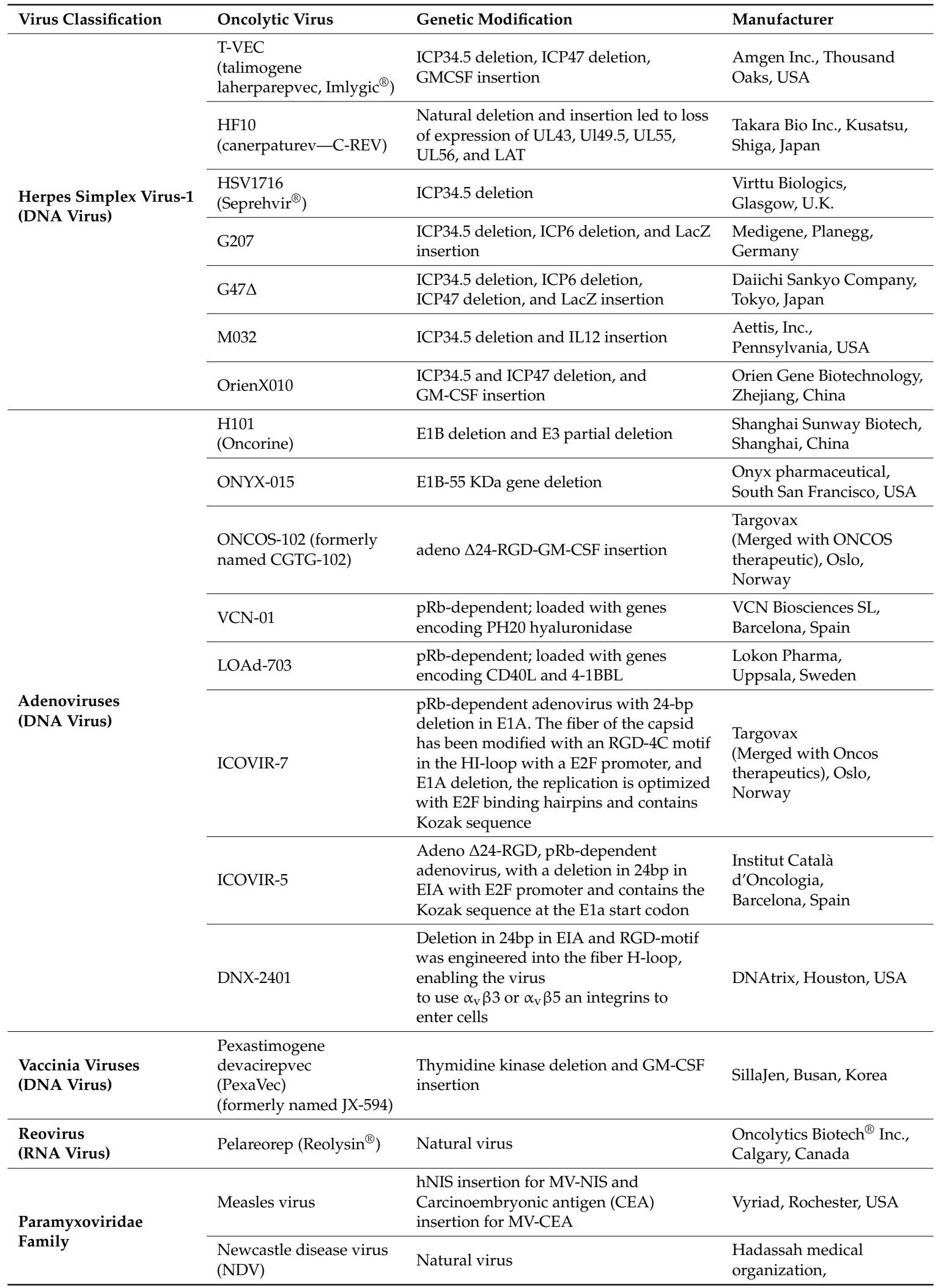


Table 1. Cont.

\begin{tabular}{|c|c|c|c|}
\hline Virus Classification & Oncolytic Virus & Genetic Modification & Manufacturer \\
\hline Parvovirus (RNA Virus) & $\begin{array}{l}\text { Parvovirus H-1 } \\
\text { (ParvOryx) }\end{array}$ & Natural virus & $\begin{array}{l}\text { ORYX Medicine, } \\
\text { Vaterstetten, Germany }\end{array}$ \\
\hline $\begin{array}{l}\text { Picornaviruses } \\
\text { (RNA Virus) }\end{array}$ & PVSRIPO & $\begin{array}{l}\text { CD155/Necl5 dependent poliovirus. The } \\
\text { internal ribosome entry site (IRES) of the } \\
\text { poliovirus replaced with the IRES from } \\
\text { human rhinovirus type } 2 \text { (HRV2) }\end{array}$ & $\begin{array}{l}\text { Duke University, } \\
\text { Durham, USA }\end{array}$ \\
\hline $\begin{array}{l}\text { Retroviral Replicating } \\
\text { Vectors }\end{array}$ & TOCA51 & $\begin{array}{l}\text { This vector is based on murine leukemia } \\
\text { virus (MLV) and carrying the yeast } \\
\text { cytosine deaminase (CD) that convert } \\
5 \text {-fluorocytosine (5-FC) into in the } \\
\text { presence of CD, to 5-fluorouracil (5-FU). }\end{array}$ & Tocagen, San Diego, USA \\
\hline
\end{tabular}

\section{Oncolytic Viruses and Melanoma Clinical Trials}

Malignant melanoma is the most common cause of mortality from skin cancer worldwide [22]. Advanced (unresectable or metastatic) melanoma is associated with the lowest survival rate, because of its refractoriness to traditional therapies, such as chemotherapy and radiotherapy $[23,24]$. As there is a significant unmet therapeutic need in malignant melanoma, the interest in cancer immunotherapy has increased lately, and the Food and Drug Administration (FDA) approved four immunotherapeutic drugs for malignant melanoma treatment.

Three of these are immune checkpoint inhibitors, including two anti-PD1 antibodies named pembrolizumab (Keytruda ${ }^{\circledR}$, Merck and Co., Inc., Kenilworth, NJ, USA) and nivolumab (Opdivo ${ }^{\circledR}$, Bristol-Myers Squibb Company, New York, NY, USA), and an anti-CTLA4 antibody called ipilimumab (Yervoy ${ }^{\circledR}$, Bristol-Myers Squibb Company) [25,26]. Moreover, in October 2015, talimogene laherparepvec (T-VEC, Imlygic ${ }^{\circledR}$ ) became the first OV ever to be approved by the FDA and EMA [27]. However, a recombinant oncolytic adenovirus named H101 (Oncorine ${ }^{\circledR}$, Shanghai Sunway Biotech) has been licensed by the China Food and Drug Administration (CFDA) for refractory head and neck carcinoma, in combination with chemotherapy, since November 2005.

\subsection{Oncolytic Herpes Simplex Virus and Melanoma Clinical Trails}

\subsubsection{Talimogene Laherparepvec (T-VEC, Imlygic ${ }^{\circledR}$ )}

T-VEC is an attenuated herpes simplex virus-1 (HSV-1) that has been modified by the insertion of human granulocyte-macrophage colony-stimulating factor (GM-CSF) in place of both loci of the ICP34.5 gene, as well as by the deletion of the ICP47 gene. These modifications increased the selective replication within tumor cells, enhancing the tumor-specific immune response [28]. Phase I, II, and III clinical trials of T-VEC have been conducted against melanoma. The clinical phase I trial of T-VEC enrolled 30 patients with different cancer types, and among them were nine patients who were pathologically diagnosed with refractory or metastatic melanoma. Every two or three weeks, patients received intratumoral injections with doses of T-VEC, which ranged from $1 \times 10^{6}$ to $1 \times 10^{8} \mathrm{pfu} / \mathrm{mL}$. Although there were no instances of complete response (CR) or partial response (PR) in this trial, as defined according to Response evaluation criteria in solid tumors (RECIST) 1.0, two patients achieved stable disease (SD), without any notable adverse events (AEs). Additionally, the lesions were flattened with evidence of necrosis [29]. This outcome supported the case for performing a clinical phase II trial of T-VEC in 50 patients with stage IIIc or IV melanoma. In this trial, patients received intratumoral T-VEC injections at a dose of $1 \times 10^{6} \mathrm{pfu} / \mathrm{mL}$ (up to $4 \mathrm{~mL}$ ) every two weeks, which was then increased to $1 \times 10^{8} \mathrm{pfu} / \mathrm{mL}$ (up to $4 \mathrm{~mL}$ ), for a total of 24 injections. The patients tolerated the therapy well, and developed only mild side effects such as a low-grade fever. In terms of outcomes, CR was achieved 
in eight patients, and PR was achieved in five patients, with a $26 \%$ overall objective response [30]. These promising results supported the use of T-VEC as an OV, and a phase III trial was therefore conducted in 436 patients with stage IIIb, IIIc, and IV unresectable melanoma. The patients were divided into two groups, 295 patients received intratumoral injections of T-VEC, and 141 patients received subcutaneous injections of recombinant GM-CSF. The objective response rate (ORR) was the primary endpoint and the overall survival rate was the secondary end point. The ORR and CR rates for T-VEC were $26 \%$ and $11 \%$, respectively, compared to $6 \%$ and $1 \%$ for recombinant GM-CSF, respectively [31-34]. After proving its safety and efficacy, T-VEC was approved by FDA, in 2015, as the first OV for the treatment of melanoma patients [27]. Recently, the favorable safety profile and the ability to enhance the immune response made T-VEC an attractive candidate for use in combination with immune checkpoint inhibitors (anti-CTLA-4 (ipilimumab) and anti-PD-1 (pembrolixzumab). In a phase II study, T-VEC was combined with ipilimumab in 198 patients, with unresectable stages IIIB to IV melanoma. The patients were divided into two groups, a combination therapy group (T-VEC and ipilimumab $(n=98))$ and a monotherapy group (ipilimumab alone $(n=100)$ ). The patients received T-VEC in the first week with $4 \mathrm{~mL}\left(1 \times 10^{6} \mathrm{pfu} / \mathrm{mL}\right)$, and in the third week the dose increased to $4 \mathrm{ml}\left(1 \times 10^{8} \mathrm{pfu} / \mathrm{mL}\right)$, repeating every two weeks. On the other hand, ipilimumab $(3 \mathrm{mg} / \mathrm{kg})$ was injected up to four doses every three weeks (in the monotherapy group, weeks $1,3,6$, and 9 , and in the combination therapy group, weeks $6,9,12$, and 15). In the injected lesions, the combination therapy (T-VEC and ipilimumab) achieved an objective response in thirty-eight patients (39\%) compared to eighteen patients $(18 \%)$ who were treated with ipilimumab alone. On the other hand, the non-injected lesions were decreased in $52 \%$ of the patients in the combination treated group, compared to $23 \%$ of the patients in the monotherapy group. This trail demonstrated that T-VEC improved the efficacy of ipilimumab by increasing the objective response by nearly double when compared with the ipilimumab treatment alone [35]. Recently, another phase Ib investigated the combination therapy between T-VEC and immune checkpoint inhibitor, anti-PD-1 (200 mg pembrolizumab/every two weeks), in patients with advanced melanoma. In this trial, twenty-one patients received $4 \mathrm{~mL}\left(1 \times 10^{6} \mathrm{pfu} / \mathrm{mL}\right)$ in the first week, and in the third week the dose was increased to $4 \mathrm{~mL}\left(1 \times 10^{8} \mathrm{pfu} / \mathrm{mL}\right)$, repeating every two weeks. The objective response was $62 \%$ with $33 \%$ complete response rate, according to the immune related response criteria. An analysis of the tumor micro-environment revealed that infiltration of CD8 T-cells was increased with a high PD-L1 expression, as well as an IFN-g gene expression [36]. These results suggest that the combination of OVs and immune checkpoint inhibitors is better than either OVs alone or immune checkpoint inhibitors alone. To date, we can notice that two oncolytic viruses (HF10 and CVA-21) shift their strategy in phase II from a single therapy to a combination therapy with immune checkpoint inhibitors (discussed below in Sections 2.1.2 and 2.1.3).

\subsubsection{HF10 (Canerpaturev-C-REV)}

The approval of T-VEC marked the start of a new era of OVs for cancer treatment. Although T-VEC is the only OV that has been approved by the FDA and EMA so far, ongoing clinical phase II trials are investigating several OVs against melanoma, which will increase the chances that more OVs will be approved in the near future (Table 2). Among them, HF10 (canerpaturev) is an attenuated HSV-1 (the same family as T-VEC) with a natural deletion of UL56, and the latency-associated transcript (LAT) $[37,38]$. A phase I trial of HF10 enrolled 28 patients with refractory solid tumors consisting of cutaneous and/or superficial lesions. In the first stage, patients received single intratumoral injections of HF10 at doses of $1 \times 10^{5}, 3 \times 10^{5}, 1 \times 10^{6}$, or $1 \times 10^{7}$ median tissue culture infective dose $\left(\mathrm{TCID}_{50}\right)$. In stage 2, the dosage of HF10 was increased from four injections of $1 \times 10^{6}$ to $1 \times 10^{7}$ $\mathrm{TCID}_{50}$. Treatment-related adverse events (AEs) were observed in $34.6 \%$ of patients, all of which were mild. Regarding the tumor response, SD was achieved in $66.7 \%(6 / 9)$ of the melanoma patients, and $13.3 \%(2 / 15)$ of the head and neck cancer patients. Neither CR nor PR were observed at the end of study, three months after the last injection of HF10. Interestingly, however, three melanoma patients showed a delayed and durable response after the end of the study [39]. The safety and tolerability of 
HF10 monotherapy was demonstrated in this phase I trial. The tumor response results supported the further investigation of HF10 in a phase II trial in melanoma patients. This trial of HF10 combined with ipilimumab (anti-CTLA-4) enrolled 46 patients (efficacy was evaluable in 44), and showed a best overall response rate as evaluated by immune-related (ir) response criteria: (irCR 18\%; irPR $23 \%$ ) of $41 \%$, with a clinical benefit rate of $68 \%$ (irCR $18 \%$, irPR $23 \%$ and irSD $27 \%$ ). Combination therapy prolonged the median overall survival time by about 26.3 months (not reached), and enhanced the efficacy of ipilimumab in melanoma patients [40,41]. Of important note, regarding HF10, whose clinical development is in progress in Japan, the new Pharmaceuticals, Medical Devices, and Other Therapeutic Products Act (PMD Act, 2014) allows for the conditional and time-limited approval of regenerative medical products, including OVs, based on demonstrated safety and estimated efficacy in small-scale clinical trials. Under this new legislation, a new drug application for HF10 will likely be submitted soon after the phase II trial.

\subsubsection{Coxsackievirus A21 (CAVATAK $\left.{ }^{\circledR}\right)$ and Melanoma Clinical Trails}

Another natural OV named CVA21 (coxsackievirus A21, CAVATAK ${ }^{\circledR}$ ), which belongs to the Picornaviridae family, was also studied in melanoma patients. CVA21 mainly binds to the N-terminal domain of intercellular adhesion molecule-1 (ICAM-1). As a consequence, CVA21's effect depends on the expression of ICAM-1 on cancer cells [42]. In theory, as ICAM-1 is overexpressed on melanoma cells relative to normal cells, CVA21 should selectively replicate within tumor cells [43]. CVA21 demonstrated its safety in a phase I trial against melanoma [44,45]. A phase II trial of CVA21 enrolled 57 patients with unresectable stage IIIc-IVM1c melanoma. The patients received intratumoral injections of CVA21 $\left(3 \times 10^{8} \mathrm{TCID}_{50}\right)$ on days one, three, five, and eight, and then every three weeks for a total of six injections. The durable response rate was $28.1 \%$ (16 of 57 patients), and $38.6 \%$ (21 of 57 patients) of the patients had immune-related progression-free survival (irPFS) six months after the treatment [46]. Parallel to these findings, the preliminary results of the phase $\mathrm{Ib}$ study (ASCO2017) evaluated the combination therapy of CVA21 with ipilimumab in patients with advanced melanoma. Twenty-six patients (13 of 26 previously treated with anti-PD-1 antibody) received $3 \times 10^{8}$ TCID $_{50}$ CVA21 on days $1,3,5,8$, and 22, followed by six injections of ipilimumab ( $3 \mathrm{mg} / \mathrm{kg}$ ), which began on day 22. The overall response rate was $38 \%$ and $88 \%$ disease control rate (DCR): (complete response (CR), partial response (PR), and stable disease (SD)) [47,48]. In the near future, the final results of CVA21 against melanoma will give us a clearer insight into the efficacy of CVA21 as a monotherapy, as well as in combination therapy with ipilimumab, for melanoma patients.

\subsection{Pelareorep $\left(\right.$ Reolysin $\left.^{\circledR}\right)$ and Melanoma Clinical Trails}

Pelareorep (Reolysin ${ }^{\circledR}$ ) is a non-enveloped, double-stranded RNA virus that depends on the Ras mutation to produce selective replication in tumor cells $[49,50]$. In a phase I trial, the adequate intravenous delivery of pelareorep was demonstrated with the administration of $3 \times 10^{10} \mathrm{TCID}_{50}$ for five consecutive days, every four weeks; this dose was defined as the maximum tolerated dose. The study showed that the administration of the virus via intravenous induced highly neutralizing antibodies (neutralizing anti-reovirus antibody (NARA) response). The NARA response might be an obstacle for efficient viral replication. Six melanoma patients showed no objective response. Moreover, viral shedding was not observed, except at 5 or 15 days in a small minority of patients [51]. One drawback of this trial is the fact that, while pelareorep may be an appropriate therapeutic approach in tumors with oncogenic Ras mutations, the presence of these mutations was not investigated in the study population. A phase II study was also conducted with pelareorep in 21 patients with metastatic melanoma. The patients received intravenous injections of $3 \times 10^{10} \mathrm{TCID}_{50}$ on days one to five in each 28-day cycle (the same schedule as in the phase I trial). The overall survival rate was 168 days, with no objective response. As a consequence, the use of pelareorep as a monotherapy in melanoma treatment did not proceed to the second stage, and was considered to be more effective in combinatorial strategies [52]. In this regard, a recent phase II study administered pelareorep, 
carboplatin, and paclitaxel to patients with advanced melanoma. On the first day, 14 patients were treated with paclitaxel $\left(200 \mathrm{mg} / \mathrm{m}^{2} ; 3 \mathrm{~h}\right.$ intravenous infusion), followed by carboplatin $(6 \mathrm{mg} / \mathrm{mL}$; $30 \mathrm{~min}$ intravenous infusion) and posteriorly with pelareorep $\left(3 \times 10^{10} \mathrm{TCID}_{50} ; 1 \mathrm{~h}\right.$ intravenous infusion). Later, only the pelareorep dose was repeated for five consecutive days. The treatment cycle was repeated every 21 days for up to eight cycles. A previous trial of a paclitaxel/carboplatin combination against melanoma showed overall response rates of $19-26 \%$. The triple combination of pelareorep/paclitaxel/carboplatin showed a $21 \%$ objective response rate (ORR), without any complete responses observed. At this point, the combination trial met the predetermined efficacy target for its first stage [53]. This trial revealed important insight regarding the strategies of combination therapies with OVs.

\subsection{Vaccinia-GM-CSF (Pexa-Vec, Formerly Named JX-594) and Melanoma Clinical Trails}

Vaccinia-GM-CSF, named pexastimogene devacirepvec (Pexa-Vec, formerly named JX-594), was used to treat melanoma patients in a clinical trial in 1999. Seven immunocompetent patients received intratumoral injections of escalating doses, ranging from $1 \times 10^{4}$ to $8 \times 10^{7} \mathrm{pfu}$, twice a week for six weeks. The trial demonstrated PR in one patient, complete remission in one patient, and a mixed response in three patients [54]. Afterwards, vaccinia-GM-CSF was named JX-594. In a phase I study, ten patients with stage IV melanoma were intratumorally injected with JX-594 $\left(1 \times 10^{8}\right.$ pfu) every week, for a total of nine injections. Two patients withdrew from the trial after the second dose [55]. Six patients showed a significant induction of GM-CSF, resulting in a $25-300 \%$ increase in neutrophil levels. In addition, JX-594 replicated well in tumor cells, with lymphocyte infiltration leading to tumor necrosis.

\subsection{Ongoing Melanoma Clinical Trails}

Currently, phase I trials for another three OVs are ongoing against melanoma, namely, ONCOS (adeno $\triangle 24-$ RGD-GM-CSF insertion) (NCT03003676), herpes virus OrienX010 (NCT03048253), and ICOVIR-5 (NCT01864759) (Table 2).

Table 2. The clinical trials of oncolytic viruses in patients with melanoma.

\begin{tabular}{|c|c|c|c|c|c|c|}
\hline Oncolytic Virus & $\begin{array}{l}\text { Clinical Trial } \\
\text { Phase }\end{array}$ & $\begin{array}{l}\text { Administration } \\
\text { Route }\end{array}$ & Combination & Status & Trial No. & References \\
\hline \multirow{9}{*}{$\begin{array}{c}\text { T-VEC } \\
\text { (Talimogene } \\
\text { Laherparepvec) }\end{array}$} & I & IT & - & Completed & PMID17121894 & [29] \\
\hline & II & IT & - & Completed & NCT00289016 & [30] \\
\hline & Launched & IT & - & Completed & $\begin{array}{l}\text { NCT01368276, } \\
\text { NCT00769704 }\end{array}$ & {$[27,31-34]$} \\
\hline & II & IT & Ipilimumab & Completed & NCT01740297 & [35] \\
\hline & $\mathrm{Ib}$ & & Pembrolizumab & Completed & NCT02263508 & [36] \\
\hline & II & IT & Pembrolizumab & Recruiting & NCT02965716 & \\
\hline & I & IT & $\begin{array}{l}\text { BRAF and MEK } \\
\text { inhibitors }\end{array}$ & Recruiting & NCT03088176 & \\
\hline & III & IT & $\begin{array}{c}\text { Dacarbazine, } \\
\text { temozolomide }\end{array}$ & Recruiting & NCT02288897 & \\
\hline & II & & Radiation & Recruiting & NCT02819843 & \\
\hline \multirow{4}{*}{$\begin{array}{c}\text { HF10 } \\
\text { (Canerpaturev- } \\
\text { C-REV) }\end{array}$} & I & IT & - & Completed & NCT01017185 & [39] \\
\hline & II & IT & - & Ongoing & NCT03153085 & \\
\hline & II & IT & Ipilimumab & Completed & NCT02272855 & {$[40,41]$} \\
\hline & II & IT & Nivolumab & Recruiting & NCT03259425 & \\
\hline
\end{tabular}


Table 2. Cont.

\begin{tabular}{|c|c|c|c|c|c|c|}
\hline Oncolytic Virus & $\begin{array}{l}\text { Clinical Trial } \\
\text { Phase }\end{array}$ & $\begin{array}{l}\text { Administration } \\
\text { Route }\end{array}$ & Combination & Status & Trial No. & References \\
\hline OrienX010 & I & IT & 一- & Recruiting & NCT03048253 & \\
\hline Oncos-102 & I & IT & $\begin{array}{l}\text { Cyclophosphamide } \\
\text { pembrolizumab }\end{array}$ & Recruiting & NCT03003676 & \\
\hline ICOVIR-5 & I & IT & - & $\begin{array}{l}\text { Completed } \\
\text { Not reported }\end{array}$ & NCT01864759 & \\
\hline \multirow{2}{*}{ Pexa Vec/JX-594 } & $\mathrm{I}$ & IV & 一 & Completed & PMID10505851 & {$[54]$} \\
\hline & II & IT & - & Completed & NCT00429312 & [55] \\
\hline \multirow{4}{*}{$\begin{array}{c}\text { Coxsackievirus } \\
\text { A21 (CVA21) } \\
\text { Cavatak }\end{array}$} & I & IT & - & Completed & NCT00438009 & {$[44,45]$} \\
\hline & II & IT & 一 & Completed & NCT01227551 & {$[46]$} \\
\hline & I & IT & Ipilimumab & Recruiting & NCT02307149 & {$[47,48]$} \\
\hline & I & IT & Pembrolizumab & Recruiting & NCT02565992 & \\
\hline \multirow{3}{*}{$\begin{array}{l}\text { Pelareorep } \\
\left.\text { (Reolysin }{ }^{\circledR}\right)\end{array}$} & I & IV & - & Completed & PMID: 18981012 & [51] \\
\hline & II & IV & - & Completed & NCT00651157 & [52] \\
\hline & II & IV & $\begin{array}{l}\text { Carboplatin/ } \\
\text { paclitaxel }\end{array}$ & Completed & NCT00984464 & [53] \\
\hline
\end{tabular}

Abbreviation: IT-intratumoral route; IV-intravenous.

\section{Oncolytic Viruses and Clinical Trials in Malignant Glioma}

Malignant glioma is the most highly invasive primary brain tumor [56]. The conventional treatment options for brain tumors are surgical resection, radiotherapy, and/or chemotherapy, depending on the tumor size, location, and pathological diagnosis. The treatment outcome is generally poor [57]. Several oncolytic viruses proved their safety and efficacy in several preclinical studies. Here, we report the oncolytic viruses that successfully transferred into the clinical trials.

\subsection{Oncolytic Herpes Simplex Virus and Glioma Clinical Trials}

Three oncolytic HSV-1 strains (HSV1716, G207, and G47 $\Delta$ ) have completed the phase I trial in glioma patients. Currently, dose-escalation phase I studies of HSV-1-M032 and HSV-1-QNestin34.5 are being done to evaluate the safety and efficacy of these OVs in malignant glioma patients [58]. The following oncolytic herpes simplex viruses were attenuated by the deletion of ICP34.5, which confers neurovirullence.

\subsubsection{HSV1716 (Seprehvir ${ }^{\circledR}$ ) and Glioma Clinical Trials}

HSV1716 (Seprehvir ${ }^{\circledR}$ ) was derived from HSV-1 strain 17 and attenuated by a mutation of ICP34.5 (deletion of $759 \mathrm{bp}$ ) [59]. A clinical phase I trial of HSV1716 enrolled nine patients with relapsed malignant glioma. The patients were intratumorally inoculated with up to $1 \times 10^{5}$ pfu of HSV1716. The treatment was tolerated well, with no induction of HSV encephalitis. Four patients survived for 24 months after the HSV1716 treatment [60]. Another clinical study of HSV1716 enrolled 12 patients with malignant glioma. In this study, patients received a single intratumoral dose of HSV1716 $\left(1 \times 10^{5} \mathrm{pfu}\right)$. After four to nine days of treatment, in 10 of the 12 patients, viral DNA was detected within the tumors. Five patients showed an immunological response through detectable changes in HSV-specific IgG and IgM. Three patients were clinically stable for an average of two years after treatment with surgery plus HSV1716 [61,62]. Recently, a phase II trial involving HSV1716 against recurrent glioma in children was completed, but the results are still pending (NCT02031965).

\subsubsection{G207, G47, and Glioma Clinical Trials}

G207 is derived from wild-type HSV-1 strain F. G207 was attenuated by a deletion in both copies of ICP34.5 and an inactivating of ICP6 by insertion of the Escherichia coli lacZ gene in UL39 [63]. A phase I trial of G207 enrolled 21 patients with glioblastoma. The following G207 doses were administered 
to three patients, $1 \times 10^{6}, 1 \times 10^{7}, 3 \times 10^{7}, 1 \times 10^{8}, 3 \times 10^{8}, 1 \times 10^{9}$, and $3 \times 10^{9}$ pfu each. The trial demonstrated that G207 inoculation into brain tumors was safe and did not lead to HSV encephalitis. Some patients had complications that are frequently associated with brain tumors, such as mental status changes, as well as dysphasia due to tumor edema, surgical trauma, or viral toxicity. This trial had some limitations, for instance, the lack of any evidence of viral replication [64]. A phase $\mathrm{Ib}$ of G207 enrolled six patients with glioma. The patients received two doses of G207 for a total $1.15 \times 10^{9} \mathrm{pfu}$. All of the patients showed stable disease after one month of G207 inoculation, without any significant AEs or the development of encephalitis. The median survival was 6.6 months after G207 administration. Viral RNA encoding HSV DNA polymerase (pol) was detected in the tumor samples of all of the patients, without viral shedding to the blood or saliva $[65,66]$. In a recent phase I trial, nine patients received one dose of G207 $\left(1 \times 10^{9} \mathrm{pfu}\right) 24 \mathrm{~h}$ prior to a single 5 Gy radiation dose. All of the patients tolerated G207 well. The median survival in this trial was 7.5 months after treatment with G207 [67]. Later, G47 $\Delta$ was created by adding another deletion of ICP47 to G207 [68]. A phase I of G47 $\Delta$ against glioma was completed, but the results have not been reported. Currently, a phase II study of G47 $\Delta$ is ongoing in patients with residual or recurrent glioblastoma in Japan [69].

\subsection{Oncolytic Adenoviruses and Glioma Clinical Trials}

ONY015 oncolytic adenovirus was evaluated in a clinical phase I trial that enrolled 24 patients with malignant glioma. Four groups of patients received different doses of ONYX015 $\left(1 \times 10^{7} \mathrm{pfu}\right.$ in cohort one; $1 \times 10^{8}$ pfu in cohort two; $1 \times 10^{9}$ pfu in cohort three; and $1 \times 10^{10}$ pfu in cohort four) in a total of 10 tumor sites. The patients showed no severe AEs, but neither antitumor effect was demonstrated, as the median survival was of only 6.2 months [70]. Another promising oncolytic adenovirus called DNX-2401 (Delta-24-RGD adenovirus) increases the viral replication selectivity through the deletion of $24 \mathrm{bp}$ in EIA and the insertion of the RGD-motif into the fiber H-loop, which enables the virus to use $\alpha v \beta 3$ or $\alpha v \beta 5$ integrins (enriched on tumor cells) to enter the tumor cells. Recently, a dose-escalation trial for DNX-2401 (Delta-24-RGD adenovirus) in patients with recurrent malignant glioma was completed. In this trial, the patients were enrolled in two groups, group A, which included twenty-five patients receiving a single dose of DNX-2401 $\left(1 \times 10^{7}-3 \times 10^{10} \mathrm{vp}\right)$, followed by monitoring for the toxicity and treatment response; and group $\mathrm{B}$, which included twelve patients who were injected with DNX-2401 $\left(1 \times 10^{7}-3 \times 10^{10} \mathrm{vp}\right)$ into multiple sites through implanted catheter, then the injection of a second dose of DNX-2401 $\left(1 \times 10^{7}-3 \times 10^{10} \mathrm{vp}\right)$ on day 14 after the tumor resection, along with a catheter, to acquire post-treatment specimens. Remarkably, in group A (single treatment), five patients (20\%) survived more than three years. Moreover, three patients out of the five patients had a $95 \%$ reduction in the tumor sizes. In group B, the post-treatment tumor specimens revealed that DNX-2401 was well replicated and induced tumor cell lysis, as well as the infiltration of CD8+ T Cells and the downregulation of transmembrane immunoglobulin mucin-3 [71,72]. This data indicates that Delta-24-RGD can achieve a durable complete response in some subsets of glioma patients. Finally, these results suggested the oncolytic effects of DNX2401, through the direct cell lysis and through enhancing the immune system, may be promising in the future for DNX2401 for combining with other immune modulatory therapies. Until now, DNX-2401 has two ongoing phase I trials; phase I study investigates the combination therapy between DNX2401 and temozolomide (NCT01956734). A multicenter phase Ib trial investigates DNX-2401 as a monotherapy or DNX-2401 in combination with interferon- $\gamma$ in recurrent glioblastoma (NCT02197169).

\subsection{Pelareorep $\left(\right.$ Reolysin $\left.^{\circledR}\right)$ and Glioma Clinical Trials}

A phase I trial of pelareorep enrolled 12 patients with grade III and IV recurrent malignant glioma, with escalating doses from $1 \times 10^{7}$ to $1 \times 10^{9} \mathrm{TCID}_{50}$. Pelareorep was injected into three intratumoral sites. Grade I and II toxicities were observed, without reaching the maximum tolerated dose. Tumor progression was observed in 10 patients, and stable disease was observed in one patient, with a median survival of 21 weeks, while only one patient had a survival of 54 months [73]. In another multicenter 
study, pelareorep was intratumorally injected in 15 patients with recurrent malignant glioma, at five different dose levels $\left(1 \times 10^{8}\right.$ to $\left.1 \times 10^{10} \mathrm{TCID}_{50}\right)$. Interestingly, pelareorep was delivered through a method known as "convection enhanced delivery", whereby pelareorep infusion into the tumor location was performed via catheter, with a continuous low pressure. Grade I and II side effects, such as seizure, were noticed in some patients. One patient experienced convulsions, a grade III AE. However, evidence of anti-tumor efficacy was observed in a few patients. Stable disease was observed in two patients, PR in one patient, and progressive disease (PD) in 12 patients. The median survival in this trial was 20 weeks, compared with 21 weeks in a previous trial [74]. Therefore, the pelareorep outcomes against glioma may be improved when combined with other therapeutic drugs such as bevacizumab (Table 3).

\subsection{Newcastle Disease Virus and Glioma Clinical Trials}

A phase I/II trial of Newcastle disease virus (NDV), HUJ strain, enrolled 11 patients with recurrent glioblastoma. The patients were divided into two groups, as follows: The first group received intravenous NDV-HUJ doses that ranged from $1 \times 10^{8}$ to $11 \times 10^{9} \mathrm{EID}_{50 \%}$ weekly, with a total of three cycles of treatment. The second group received intravenous $11 \times 10^{9} \mathrm{EID}_{50 \%}$ weekly, for a total of three cycles. The intravenous treatment was well tolerated. Grade I and II side effects such as fever, seizures, stupor, syncope, headache, abdominal pain, and hypertension were observed in five patients. The median survival was 33.2 weeks. Of note, $C R$ was observed in one patient [75]. However, since 2005, no other studies have evaluated the NDV-HUJ virus in glioblastoma patients.

\subsection{ParvOryx and Glioma Clinical Trials}

Recently, a trial of Parvovirus H-1 (ParvOryx) enrolled 18 patients with malignant glioma. ParvOryx was administered on two different schedules, as follows: The first used a single dose of ParvOryx injected intratumorally, with re-injection on day 10 after surgical resection. The second included five doses of ParvOryx injected intravenously, with intratumoral re-injection on day 10, after surgical resection. ParvOryx was well tolerated without a dose-dependent toxicity, regardless of the administration schedule. This trial was very important as it was the first to prove that ParvOryx could cross the blood-brain/tumor barrier in both directions. Moreover, ParvOryx induced the infiltration of T-cells, microglia, and macrophages within tumors, with a low number of infiltrated regulatory T-cells (Treg). This is the first study to provide a detailed description of the tumor immune response in glioma patients after treatment with an OV, through the detection of Tregs and several activation markers for immune cells, including perforin, granzyme B, interferon- $\gamma$, interleukin 2 (IL-2), CD40L, and CD25 [76].

\subsection{Poliovirus and Glioma Clinical Trials}

PVSRIPO is an attenuated poliovirus type 1 (Sabin), and its cognate internal ribosome entry site is replaced with the internal ribosome entry site of human rhinovirus type 2. PVSRIPO mainly binds to the poliovirus receptor CD155. CD155 is widely expressed in solid tumors. A dose-escalation trial was designed for five doses levels $\left(1 \times 10^{8} \mathrm{TCID}_{50}\right.$ /one patient, $3.3 \times 10^{8} \mathrm{TCID}_{50}$ /one patient, $1 \times 10^{9} \mathrm{TCID}_{50}$ /one patient, $3.3 \times 10^{9} \mathrm{TCID}_{50} /$ two patients, and $1 \times 10^{10} \mathrm{TCID}_{50} /$ four patients) This escalation study revealed that $1 \times 10^{10} \mathrm{TCID}_{50}$ is the dose limiting due to one patient had a grade 4 intracranial hemorrhage. In the dose expansion phase, six patients received $3.3 \times 10^{8}$ $\mathrm{TCID}_{50}, 31$ patients received $5 \times 10^{7} \mathrm{TCID}_{50}$, and 15 patients received $1 \times 10^{7} \mathrm{TCID}_{50}$. However, viral neuropathogenicity was not observed in the treated patients. A grade 3 or higher adverse event was observed in $19 \%$ of the patients, which related to PVSRIPO. Hence, a $5 \times 10^{7} \mathrm{TCID}_{50}$ dose level was determined for future phase II. Interestingly, the overall survival was $21 \%$, which is higher than the rate among historical controls [77]. In conclusion, several OVs have clearly demonstrated both safety and promising efficacy in phase I trials in glioma patients. Consequently, several of these OVs will most likely be investigated in phase II trials in the near future. 


\subsection{Ongoing Glioma Clinical Trials}

Clinical trials of three OVs have been initiated and are enrolling patients with glioma, measles virus CEA (NCT00390299), Toca 511 (NCT02576665), and vaccinia virus TG6002 (NCT03294486) (Table 3).

Table 3. The clinical trials of oncolytic viruses in patients with glioma.

\begin{tabular}{|c|c|c|c|c|c|c|}
\hline Oncolytic Virus & Phase & Administration Route & Combination & Status & Trial No. & Reference \\
\hline \multirow{3}{*}{$\begin{array}{l}\text { HSV1716 } \\
\text { Seprehvir }^{\circledR}\end{array}$} & I & IT & - & Completed & PMID10845724 & [60] \\
\hline & $\mathrm{Ib}$ & IT & - & Completed & $\begin{array}{l}\text { PMID11960316, } \\
\text { PMID15334111 }\end{array}$ & {$[61,62]$} \\
\hline & II & IT & - & $\begin{array}{l}\text { Completed } \\
\text { Not reported }\end{array}$ & NCT02031965 & \\
\hline \multirow{3}{*}{ G207 } & I & IT & - & Completed & NCT00028158 & [64] \\
\hline & $\mathrm{Ib}$ & IT & - & Completed & NCT00157703 & {$[65,66]$} \\
\hline & I & IT & $\begin{array}{l}\text { 5Gy radiation } \\
\text { dose }\end{array}$ & Completed & NCT00157703. & [67] \\
\hline \multirow{2}{*}{ G47 $\Delta$} & I & IT & - & $\begin{array}{l}\text { Completed } \\
\text { Not reported }\end{array}$ & & [69] \\
\hline & II & IT & - & Ongoing & UMIN000011636 & [69] \\
\hline MO32 & I & IT & & Ongoing & NCT02062827 & [58] \\
\hline rQNestin & I & IT & & Recruiting & NCT03152318 & \\
\hline ONYX-015 & I & IT & - & Completed & PMID15509513 & [70] \\
\hline \multirow{3}{*}{$\begin{array}{c}\text { Adeno-Delta- } \\
\text { 24-RGD } \\
\text { (DNX-2401) }\end{array}$} & I & IT & - & Completed & & {$[71,72]$} \\
\hline & I & & temozolomide & Ongoing & NCT01956734 & \\
\hline & I & & interferon- $\gamma$ & Ongoing & NCT02197169 & \\
\hline \multirow{2}{*}{$\begin{array}{l}\text { Pelareorep } \\
\left(\text { Reolysin }^{\circledR}\right)\end{array}$} & I & IV & - & Completed & NCT00528684 & [73] \\
\hline & I & IV & - & Completed & PMID: 24553100 & [74] \\
\hline $\begin{array}{c}\text { Newcastle } \\
\text { Disease Virus } \\
\text { (NDV) }\end{array}$ & $\mathrm{I} / \mathrm{II}$ & IT & - & Completed & NCT01174537 & [75] \\
\hline $\begin{array}{c}\text { Parvovirus H-1 } \\
\text { (ParvOryx) }\end{array}$ & I & IT and IV & - & Completed & NCT01301430 & [76] \\
\hline $\begin{array}{c}\text { Measles virus } \\
\text { CEA }\end{array}$ & I & IT & - & Ongoing & (NCT00390299) & \\
\hline $\begin{array}{l}\text { Poliovirus } \\
\text { PVSRIPO }\end{array}$ & I & IT & - & Completed & (NCT01491893) & [77] \\
\hline Toca 511 & I & IT & - & Ongoing & (NCT02576665) & \\
\hline $\begin{array}{l}\text { Vaccinia virus } \\
\text { TG6002 }\end{array}$ & I & IT & - & Ongoing & (NCT03294486) & \\
\hline
\end{tabular}

\section{Oncolytic Viruses and Pancreatic Cancer}

Pancreatic cancer is one of the major causes of cancer-related deaths worldwide [78], with the majority of these caused by pancreatic adenocarcinoma, the most prevalent subtype [79]. Pancreatic ductal adenocarcinoma (PDAC) does not express neoantigens, which consequently limit the priming of T-cells and the overall immune response [80]. Moreover, the pancreatic tumor microenvironment is enriched with immunosuppressive factors such as Tregs, M2 tumor-associated macrophages, IL-10, and transforming growth factor- beta (TGF- $\beta$ ). In addition, pancreatic tumors are primarily composed of fibrotic tissue and stellate cells, which together act as a natural physical barrier that renders the extracellular matrix impenetrable [81]. The combination of these factors limits the efficacy of both chemotherapy and immunotherapy [82-84]. Several chemotherapeutic drugs had been approved against PDAC, such as gemcitabine, folfirinox, and nab-paclitaxel, but all have been associated with severe side effects and only modest survival rates $[85,86]$. However, immune checkpoint inhibitors have shown significant efficacy against other types of cancer, such as melanoma. The efficacy of these drugs is still under investigation, and clinical trials against pancreatic cancer are ongoing [87]. 
On the other hand, several OVs were investigated in preclinical pancreatic models, either alone or in combination with chemotherapeutic drugs such as gemcitabine. Furthermore, some OVs are already under investigation in phase I and II clinical trials. Here, we will review the completed clinical trials of different OVs against pancreatic cancer (Table 4).

\subsection{Oncolytic Adenoviruses and Pancreatic Clinical Trials}

Oncolytic adenoviruses have been developed and investigated in preclinical pancreatic models. So far, the results of the phase I and II trials in PDAC patients have been reported only for the oncolytic ONYX-015 adenovirus. ONYX-015 (d11520) is an E1B-55 kDa gene-deleted virus that replicates selectively in p53-mutated tumor cells [88]. A phase I trial of ONYX-015 enrolled 23 patients with unresectable pancreatic cancer. The patients were administered ONYX-015 $\left(1 \times 10^{8}\right.$ to $1 \times 10^{11} \mathrm{pfu}$ ) every four weeks via computed tomography (CT)-guided injection. All of the patients tolerated ONYX-015 without significant complications, except for one, who experienced transient pancreatitis [89]. High levels of neutralizing antibodies were observed in all of the patients who received treatment; moreover, viral replication was not detected by PCR in the blood or by fine needle aspirates. The authors highlighted the following two possible limitations regarding the detection of viral replication within tumors: (1) the aspirated samples from tumors were mainly composed of necrotic cells with few viable cells, and (2) the physical barriers of tumors limited viral replication. Overall, an objective response was not observed in this trial [89]. However, the results of this phase I trial supported the safety of ONYX015 and suggest that it is reasonable to test it as part of combination therapy. A phase II trial of ONYX015 combined with gemcitabine enrolled 21 patients with advanced and metastatic pancreatic adenocarcinoma [90]. The majority of patients received $2 \times 10^{11} \mathrm{pfu}$ ONYX015 via endoscopic ultrasound (EUS) guidance over eight weeks, with three patients receiving only $2 \times 10^{10} \mathrm{pfu}$, while gemcitabine (intravenous, $1000 \mathrm{mg} / \mathrm{m}^{2}$ ) was administered during the final four weeks. A clinical response was not noted after treatment with ONYX-015 alone. However, after the administration of gemcitabine, six patients demonstrated SD, two showed partial regression, and two had a minor response; in all of these cases there were no severe side effects. Although this trial proved the significance of ONYX015 administration with EUS guidance, it did not overcome the problems of phase I, such as viral replication and the elevation of neutralizing antibodies, which represent a major challenge regarding treatment using OVs. In addition, ONYX015 showed limited efficacy, even in combination with gemcitabine [90]. Two other oncolytic adenoviruses, VCN-01 and LOAd703, are currently being evaluated in ongoing phase I trials, either alone or combined with nab-paclitaxel/gemcitabine in patients with metastatic pancreatic adenocarcinoma (NCT02705196, NCT02045589, and NCT02045602).

\subsection{Oncolytic Herpes Simplex Viruses and Pancreatic Clinical Trials}

Seven oncolytic herpes simplex viruses are currently under investigation in multiple phase II clinical trials in different types of solid tumors (Table 1). Only, HF10 and T-VEC were evaluated in clinical trials in pancreatic cancer patients (Table 4). In the investigator-initiated phase I trial of HF10 monotherapy, eight patients with pancreatic ductal carcinoma were enrolled and treated. HF10 $\left(1 \times 10^{5}\right.$ to $\left.1 \times 10^{6} \mathrm{pfu}\right)$ was intratumorally injected for three consecutive days, with the first dose injected during laparotomy. An intratumoral catheter was also inserted during surgery, to inject the other two doses of HF10. All of the patients tolerated the treatment well. without any treatment-related severe AEs. SD was observed in three patients, PR in one patient, and PD in the remaining patients. Three patients declined measurement of the tumor marker CA19.9. The trial reported interesting results about immune response after treatment. HF10 triggered the infiltration of macrophages and CD4 ${ }^{+}$ and $\mathrm{CD}^{+} \mathrm{T}$ cells, as well as the activation of natural killer (NK) cells. The median progression free survival rate was six months [91,92]. A new HF10 phase I trial in patients with unresectable pancreatic cancer is in progress to assess the safety and efficacy of HF10 in combination with gemcitabine and nab-paclitaxel, as well as in combination with S-1 (tegafur/gimeracil/oteracil, TS-1 ${ }^{\circledR}$ ) (NCT03252808). 
Another phase I trial of T-VEC enrolled 17 patients with pancreatic cancer. The preliminary results showed that the initial doses of T-VEC $\left(1 \times 10^{4}\right.$ to $\left.1 \times 10^{6} \mathrm{pfu} / \mathrm{mL}\right)$ were tolerated well, with the exception of two patients who experienced grade 5 AEs (not related to the T-VEC injection) without any objective response [93]. Another HSV-1 OV, Orien X010, is a recombinant hGM-CSF HSV-1 that is still ongoing in a phase I trial against pancreatic cancer (NCT01935453).

Table 4. The clinical trials of oncolytic viruses in patients with pancreatic cancer.

\begin{tabular}{|c|c|c|c|c|c|c|}
\hline Oncolytic Virus & $\begin{array}{l}\text { Clinical Trial } \\
\text { Phase }\end{array}$ & $\begin{array}{l}\text { Administration } \\
\text { Route }\end{array}$ & Combination & Status & Trial No & Reference \\
\hline \multirow{2}{*}{$\begin{array}{l}\text { T-VEC (Talimogene } \\
\text { laherparepvec) }\end{array}$} & I & IT & - & Completed & NCT00402025 & [93] \\
\hline & I & IT & - & Recruiting & NCT03086642 & \\
\hline \multirow{2}{*}{$\begin{array}{c}\text { HF10 } \\
\text { (canerpaturev, C-REV) }\end{array}$} & IIT & IT & - & Completed & PMID29801474 & {$[91,92]$} \\
\hline & I & IT & $\begin{array}{l}\text { Nab-Paclitaxel + } \\
\text { Gemcitabine/S-1 }\end{array}$ & Ongoing & NCT03252808 & \\
\hline Orien $X 010$ & I & IT & - & Ongoing & NCT01935453 & \\
\hline \multirow{2}{*}{ ONYX-015 } & I & IT & - & Completed & PMID11313805 & [89] \\
\hline & II & IT & Gemcitabine & Completed & PMID12576418 & [90] \\
\hline VCN-01 & I & IT \&IV & $\begin{array}{l}\text { Nab-Paclitaxel/ } \\
\text { Gemcitabine }\end{array}$ & Recruiting & NCT02045589 & \\
\hline LOAd703 & I & IT & Gemcitabine & Recruiting & NCT02705196 & \\
\hline $\begin{array}{c}\text { Parvovirus H-1 } \\
\text { (ParvOryx) }\end{array}$ & I & IT \& IV & - & Recruiting & NCT02653313 & \\
\hline \multirow{3}{*}{$\begin{array}{l}\text { Pelareorep } \\
\left.\text { (Reolysin }^{\circledR}\right)\end{array}$} & II & IV & $\begin{array}{l}\text { Carboplatin/ } \\
\text { paclitaxel }\end{array}$ & Completed & NCT01280058 & [94] \\
\hline & II & IV & Gemcitabine & Completed & NCT00998322 & [95] \\
\hline & $\mathrm{I}$ & IV & Pembrolizumab & Ongoing & NCT02620423 & \\
\hline
\end{tabular}

\subsection{Pelareorep (Reolysin ${ }^{\circledR}$ ) and Pancreatic Clinical Trials}

Pelareorep (Reolysin ${ }^{\circledR}$ ), was also tested in order to compare combined therapy with carboplatin and paclitaxel in a randomized phase II in naïve patients with metastatic pancreatic adenocarcinoma. In this trial, 36 patients who received triple combination therapy with paclitaxel/carboplatin and pelareorep were compared with 37 patients who received only combined chemotherapy with paclitaxel/carboplatin. There was no difference in the progression-free survival between the triple therapy (4.9 months) and chemotherapy groups (5.2 months). This trial demonstrated significant changes in the immunophenotypes of patients, specifically higher levels of circulating T-cells, NK cells, and proinflammatory plasma chemokines and cytokines, including IL-1 $\beta$, IL-2, IL-6, IL-12p70, IL-13, IL-17A, IL-17F, IP-10, regulated on activation, normal T cell expressed and secreted (RANTES), and vascular endothelial growth factor-A (VEGFA) [94]. A separate a case report showed the first evidence of reovirus protein in a primary tumor biopsy from a pancreatic cancer patient after treatment with pelareorep and gemcitabine combination therapy [95]. In conclusion, pelareorep as a monotherapy failed to improve the progression-free survival. As a consequence, in phase II, pelareorep was combined with gemcitabine in pancreatic cancer patients. Thirty-four patients with pancreatic cancer (chemotherapy naïve patients) were enrolled in this study. On days one and eight, patients received $800 \mathrm{mg} / \mathrm{m}^{2}$ gemcitabine IV over $30 \mathrm{~min}$. Moreover, on days one, two, eight, and nine, pelareorep $\left(1 \times 10^{10} \mathrm{TCID}_{50}\right)$ was intravenously injected over $60 \mathrm{~min}$ in a three-week cycle. This combination was well tolerated, with manageable nonhematological toxicities. The study showed that one patient had partial response, 23 patients had stable disease, and five patients had a progressive disease. CA19.9 was decreased ( $20 \%$ from baseline) in $70 \%$ of the patients, with 10.2 months as the median overall survival. Pelareorep was replicated well in pancreatic tumors [96]. The single post-treatment biopsy using immunohistochemistry (IHC) revealed a high PD-L1 expression, which suggests that the combination of Reolysin ${ }^{\circledR}$ and anti-PDL-1 may be more effective in further clinical trials. 
Currently, a phase I clinical trial of pelareorep in combination with pembrolizumab (PD-1 blockade) is ongoing in pancreatic cancer patients (NCT02620423). In addition, a phase I trial of ParvOryx is currently recruiting patients with pancreatic cancer (NCT02653313) (Table 4). In conclusion, phase I trials have been completed for only four OVs (HF10, T-VEC, ONYX-015, and pelareorep) as a monotherapy. However, the results indicate that these OVs are not yet adequate as future monotherapies. As a consequence, further clinical trials of OVs against PDA must be conducted to prove their efficacy as either a monotherapy or as part of combination therapy.

\section{Oncolytic Viruses and Breast Cancer}

Breast cancer is the most commonly diagnosed cancer among women, and the second most common cause of cancer-related deaths among women [97]. The treatment of breast cancer has advanced over the past decade, and targeted therapies have been developed, improving survival rates. However, there are still treatment-resistant cases and thus further treatment options, such as OVs, are necessary. OVs have shown promising therapeutic efficacy when used as a monotherapy in preclinical breast cancer models. Currently, different types of OVs are being investigated in clinical trials in breast cancer patients (Table 5).

Table 5. The clinical trials of oncolytic viruses in patients with breast cancer.

\begin{tabular}{|c|c|c|c|c|c|c|}
\hline Oncolytic Virus & $\begin{array}{l}\text { Clinical Trial } \\
\text { Phase }\end{array}$ & $\begin{array}{l}\text { Administration } \\
\text { Route }\end{array}$ & Combination & Status & Trial No. & Reference \\
\hline $\begin{array}{l}\text { T-VEC (Talimogene } \\
\text { laherparepvec) }\end{array}$ & I & IT & - & Completed & PMID17121894 & [29] \\
\hline $\begin{array}{c}\text { HF10 } \\
\text { (canerpaturev-C-REV) }\end{array}$ & IIT & IT & - & Completed & PMID16865590 & {$[98,99]$} \\
\hline ONYX-015 & I & IT & Enbrel & Completed & PMID17704755 & [100] \\
\hline ICOVIR-7 & $\mathrm{I}$ & IT & - & Completed & PMID20501623 & [101] \\
\hline $\begin{array}{l}\text { Vaccinia Virus } \\
\left(\mathbf{V V}_{\mathrm{DD}}\right)\end{array}$ & I & IT & - & Completed & PMID25292189 & [102] \\
\hline PV701 & & IV & - & Completed & PMID16638865 & [103] \\
\hline CVA21 & I & IT & - & $\begin{array}{l}\text { Completed } \\
\text { Not reported }\end{array}$ & NCT00636558 & \\
\hline \multirow{2}{*}{$\begin{array}{l}\text { Measles Virus } \\
\text { (MV)-NIS }\end{array}$} & $\mathrm{I}$ & IT & - & Ongoing & NCT01846091 & \\
\hline & I & IT & - & Recruiting & NCT01376505 & \\
\hline \multirow{2}{*}{$\begin{array}{l}\text { Pelareorep } \\
\left(\text { Reolysin }^{\circledR}\right)\end{array}$} & I & IV & - & Completed & PMID19572105 & [104] \\
\hline & II & IV & Paclitaxel & Completed & NCT01656538 & [105] \\
\hline
\end{tabular}

\subsection{Oncolytic Herpes Simplex Virus and Breast Cancer Clinical Trials}

An investigator-initiated phase I trial of HF10 enrolled six patients with cutaneous and subcutaneous metastatic breast cancer. HF10 $\left(1 \times 10^{4}: 5 \times 10^{5} \mathrm{pfu} / 0.5 \mathrm{~mL} /\right.$ nodule $)$ was intratumorally injected for three consecutive days. All of the patients tolerated the treatment well, and there were no reported AEs. HF10 viral inclusion bodies demonstrated a high replication selectivity in the tumor cells only. A histological examination revealed fibrosis and tumor cell death with an infiltration of CD8 ${ }^{+}$ and $\mathrm{CD} 4^{+} \mathrm{T}$-cells around tumor islets, findings that support the induction of an immune response by HF10 $[98,99]$. This phase I trial was concluded in 2006, and there have yet to be any phase II trials of HF10. A phase I trial of HSV-1 T-VEC enrolled 14 patients with metastatic breast cancer. The patients received an intratumoral injection of T-VEC $\left(1 \times 10^{6}: 1 \times 10^{8} \mathrm{pfu} / \mathrm{mL}\right)$. All of the patients tolerated the treatment well and exhibited only grade I AEs. This therapy achieved SD in some patients, but no CR or PR. Of note, T-VEC induced necrosis of tumor cells [29].

\subsection{Oncolytic Adenovirus and Breast Cancer Clinical Trials}

A phase I trial investigated the OV adenovirus ONYX-015 in combination with etanercept (Enbrel ${ }^{\circledR}$, a recombinant dimer of the human tumor necrosis factor $\alpha$ receptor). This study enrolled 
two patients with metastatic breast cancer, as well as other patients with different types of cancer. Each patient received a total of 79 injections of ONYX-015 $\left(1 \times 10^{12} \mathrm{vp}\right.$ for 4 weeks/cycle $)$ and a subcutaneous injection of etanercept (only in cycle 1). The patients showed a transient grade I and II fever within $24 \mathrm{~h}$ of the ONYX-015 infusion. The patients with breast cancer showed PD with a mean survival of only 125 days. However, ONYX-015 also resulted in SD in the patients with colon cancer, demonstrating its effectiveness in colon cancer, but not in breast cancer [100].

Another clinical phase I trial using an oncolytic adenovirus, called ICOVIR-7, enrolled three patients with breast cancer. The patients received three intratumoral injections of ICOVIR-7 $\left(1 \times 10^{11} \mathrm{vp}\right)$. One patient showed a stabilization of tumor markers, while the other patients demonstrated a negative viral genome at days 0,2 , and 7 . However, at the endpoint, none of the patients showed an effective response (mild, partial, or complete response) [101].

\subsection{Pelareorep (Reolysin $\left.{ }^{\circledR}\right)$ and Breast Cancer Clinical Trials}

A single-center, dose-escalation trial of pelareorep included two patients with breast cancer. The patients received intravenous doses ranging from $1 \times 10^{8}$ to $3 \times 10^{10}$ TCID $_{50}$ every four weeks. One patient showed a PR with tumor shrinkage (34\%) by RECIST criteria after five treatment cycles. Specifically, this patient showed high level of the RAS mutation, which led to the efficient viral replication and lysis of the tumor tissue. This response lasted for nine weeks [104]. A phase II clinical trial of pelareorep in combination with paclitaxel has been completed in patients with metastatic breast cancer. In this trial, seventy-four women were randomized into two arms. In arm A, 36 patients received paxlitaxel in combination with pelareorep, while 38 arm B patients received paclitaxel alone. The patients in both arms received $80 \mathrm{mg} / \mathrm{m}^{2}$ paclitaxel on days 1,8 , and 1, every 28 days, while in $\operatorname{arm} \mathrm{A}$, the patients received intravenously pelareorep $3 \times 10^{10} \mathrm{TCID}_{50}$ for $1 \mathrm{~h}$ on days $1,2,8,9,15$, and 16. This trial showed that pelareorep was well tolerated. However, there was no significant difference in the progression-free survival (PFS) as a primary endpoint, and the median overall survival in arm A was significantly longer than arm B (17.4 and 10.4 months, respectively). This trial suggests that the combination of paclitaxel and pelareorep is more effective than paclitaxel alone [105].

\subsection{Vaccinia Virus $\left(V V_{D D}\right)$ and Breast Cancer Clinical Trials}

Vaccinia virus $\left(\mathrm{VV}_{\mathrm{DD}}\right)$ is genetically modified by the deletion of two essential genes, vaccinia growth factor and thymidine kinase, in order to acquire a tumor-only replication capacity. A trial of $\mathrm{VV}_{\mathrm{DD}}$ enrolled four patients with breast cancer who were intratumorally injected with $3 \times 10^{7} \mathrm{pfu}$. $\mathrm{VV}_{\mathrm{DD}}$ was well tolerated and demonstrated a high selective replication in tumor cells. One patient showed grade 3 side effects, such as hemorrhage, while two patients showed an antitumor response, namely the presence of ulcerated and erythematous lesions due to viral replication [102].

\subsection{Newcastle Disease Virus and Breast Cancer Clinical Trials}

PV701, a Newcastle disease virus, was investigated in a phase I trial that enrolled two patients with breast cancer. The primary endpoint was to the maximal dosage, which could be used without toxicity. The first and second intravenously injected PV701 doses were $1 \times 10^{9} \mathrm{pfu} / \mathrm{m} 2$ and $12 \times 10^{9} \mathrm{pfu} / \mathrm{m}^{2}$, respectively, followed by dose increases from $24 \times 10^{9} \mathrm{pfu} / \mathrm{m}^{2}$ to $120 \times 10^{9} \mathrm{pfu} / \mathrm{m}^{2}$ for the third to sixth doses. PV701 was administered for an average of three completed treatment cycles. The treatment regimen was well tolerated. Mild flu-like symptoms were commonly observed after the first dose, but disappeared with repeated dosing. Moreover, dose-dependent toxicity was not observed. One of the patients showed prolonged SD for about six months [103]. Overall, several OVs were investigated in the phase I clinical trials in the patients with advanced breast cancer. The safety of these OVs was proven in these trials, but the outcomes are insufficient to warrant the use of OVs as a monotherapy against breast cancer at this time. 


\section{Future Prospective OV Clinical Trials}

Although interest in using OVs in cancer therapy increased after the FDA approval of T-VEC in 2015, there are several obstacles in the development of additional oncolytic virotherapies against different cancer types. The main difficulty involves optimizing the delivery system, as the majority of OVs, except for pelareorep (Reolysin ${ }^{\circledR}$ ), were delivered locally via direct intratumoral injection. As noted in this review, some trials attempted to optimize the OV administration using EUS guidance, a system that requires improvement in order to increase the efficacy of OV delivery against different cancer types. A second obstacle is that while the effects of OVs depend on enhancing either the innate or adaptive immune response, the immune response can also suppress viral replication, which might decrease viral oncolysis. As a consequence, the immune response needs to be balanced in favor of viral and tumor antigens. Third, pre-existing antibodies can also suppress OV efficacy when administered intravenously. Hence, coating OVs may allow for other administration options. Fourth, the strategy of combining OVs with chemotherapeutic or immunotherapeutic drugs requires further optimization, because the optimal order in which to administer these therapies is not yet clear. Finally, prognostic biomarkers for oncolytic virotherapy are needed in the future.

Author Contributions: I.R.E., mainly preparing manuscript, collecting data, designing, writing, and editing; I.B.-V., editing and writing; Y.N., mainly revising the manuscript and providing critical considerations for manuscript design and editing; T.I. and S.M., manuscript collecting data and editing; M.T., contributing to revising the manuscript; W.Z., D.M., N.MI., N.MU., H.H., S.S., B.A., and Y.K., contributing to manuscript design and collecting data; H.K., revising the manuscript and providing critical considerations for manuscript design, as well as final approval of the version to be published.

Funding: This work was supported by a 2016 Grant-in-Aid for challenging Exploratory Research (16K15611).

Acknowledgments: The authors are grateful to Yukihiro Nishiyama, who isolated the HF10 oncolytic virus at the Department of Virology, Nagoya University Graduate School of Medicine. The authors would like to thank Emi Uematsu for her technical efforts. Also, we would like to thank the secretaries of the Office of International Affairs-Mika Kasai Prince, Miho Kobayashi, and Yumiko Samizo.

Conflicts of Interest: The authors, except Maki Tanaka, have declared that no competing interest exists. Maki Tanaka is an employee of Takara Bio, Inc. HK is provided with a research funding from Takara Bio, Inc. The funding sponsor (Takara Bio, Inc.) had no role in the design of the study; in the collection, analyses, or interpretation of data; in the writing of the manuscript; and in the decision to publish this review.

\section{References}

1. Dock, G. The Influence of Complicating Diseases upon Leukaemia. Am. J. Med. Sci. 1904, 127, $563-592$. [CrossRef]

2. Levaditi, C.; Nicolau, S. Vaccine Et Neoplasmes. Ann. Inst. Pasteur 1923, 37, 443-447.

3. Rivers, T.M.; Pearce, L. Growth and Persistence of Filterable Viruses in a Transplantable Rabbit Neoplasm. J. Exp. Med. 1925, 42, 523-537. [CrossRef] [PubMed]

4. Moore, A.E. Viruses with Oncolytic Properties and their Adaptation to Tumors. Ann. N. Y. Acad. Sci. 1952, 54, 945-952. [CrossRef] [PubMed]

5. Pack, G.T. Note on the Experimental use of Rabies Vaccine for Melanomatosis. AMA Arch. Derm. Syphil. 1950, 62, 694-695. [CrossRef]

6. Hoster, H.A.; Zanes, R.P.; von Haam, E. Studies in Hodgkin's Syndrome: IX. the Association of "Viral" Hepatitis and Hodgkin's Disease (A Preliminary Report). Cancer Res. 1949, 9, 473-480. [PubMed]

7. Weller, T.H.; Robbins, F.C.; Enders, J.F. Cultivation of Poliomyelitis Virus in Cultures of Human Foreskin and Embryonic Tissues. Proc. Soc. Exp. Biol. Med. 1949, 72, 153-155. [CrossRef] [PubMed]

8. Gey, G.; Coffman, W.D.; Kubicek, M.T. Tissue Culture Studies of the Proliferative Capacity of Cervical Carcinoma and Normal Epithelium. Cancer Res. 1952, 12, 264-265.

9. Moore, A.E. The Destructive Effect of the Virus of Russian Far East Encephalitis on the Transplantable Mouse Sarcoma 180. Cancer 1949, 2, 525-534. [CrossRef]

10. Sharpless, G.R.; Davies, M.C.; Cox, H.R. Antagonistic Action of Certain Neurotropic Viruses Toward a Lymphoid Tumor in Chickens with Resulting Immunity. Exp. Biol. Med. 1950, 73, 270-275. [CrossRef] 
11. Moore, A.E.; O'Connor, S. Further Studies on the Destructive Effect of the Virus of Russian Far East Encephalitis on the Transplantable Mouse Sarcoma 180. Cancer 1950, 3, 886-890. [CrossRef]

12. Smith, R.R.; Huebner, R.J.; Rowe, W.P.; Schatten, W.E.; Thomas, L.B. Studies on the use of Viruses in the Treatment of Carcinoma of the Cervix. Cancer 1956, 9, 1211-1218. [CrossRef]

13. Ginder, D.R.; Friedewald, W.F. Effect of Semliki Forest Virus on Rabbit Fibroma. Exp. Biol. Med. 1951, 77, 272-276. [CrossRef]

14. Lindenmann, J.; Klein, P.A. Immunity to Transplantable Tumors Following Viral Oncolysis. J. Immunol. 1965, 94, 461-466. [PubMed]

15. Gross, S. Measles and Leukaemia. Lancet 1971, 297, 397-398. [CrossRef]

16. Mitus, A.; Holloway, A.; Evans, A.E.; Enders, J.F. Attenuated Measles Vaccine in Children with Acute Leukemia. Am. J. Dis. Child. 1962, 103, 413-418. [CrossRef] [PubMed]

17. Pasquinucci, G. Possible Effect of Measles on Leukaemia. Lancet 1971, 297, 136. [CrossRef]

18. Zygiert, Z. Hodgkin's Disease: Remissions After Measles. Lancet 1971, 297, 593. [CrossRef]

19. Taqi, A.M.; Abdurrahman, M.B.; Yakubu, A.M.; Fleming, A.F. Regression of Hodgkin's Disease After Measles. Lancet 1981, 317, 1112. [CrossRef]

20. Bluming, A.; Ziegler, J. Regression of Burkitt's Lymphoma in Association with Measles Infection. Lancet 1971, 298, 105-106. [CrossRef]

21. Martuza, R.L.; Malick, A. Experimental Therapy of Human Glioma by Means of a Genetically Engineered Virus Mutant. Science 1991, 252, 854-856. [CrossRef] [PubMed]

22. Ferlay, J.; Shin, H.; Bray, F.; Forman, D.; Mathers, C.; Parkin, D.M. Estimates of Worldwide Burden of Cancer in 2008: GLOBOCAN 2008. Int. J. Cancer 2010, 127, 2893-2917. [CrossRef] [PubMed]

23. Korn, E.L.; Liu, P.; Lee, S.J.; Chapman, J.W.; Niedzwiecki, D.; Suman, V.J.; Moon, J.; Sondak, V.K.; Atkins, M.B.; Eisenhauer, E.A. Meta-Analysis of Phase II Cooperative Group Trials in Metastatic Stage IV Melanoma to Determine Progression-Free and overall Survival Benchmarks for Future Phase II Trials. J. Clin. Oncol. 2008, 26, 527-534. [CrossRef] [PubMed]

24. Johnson, T.M.; Smith, J.W.; Nelson, B.R.; Chang, A. Current Therapy for Cutaneous Melanoma. J. Am. Acad. Dermatol. 1995, 32, 689-707. [CrossRef]

25. Hodi, F.S.; O'day, S.J.; McDermott, D.F.; Weber, R.W.; Sosman, J.A.; Haanen, J.B.; Gonzalez, R.; Robert, C.; Schadendorf, D.; Hassel, J.C. Improved Survival with Ipilimumab in Patients with Metastatic Melanoma. N. Engl. J. Med. 2010, 363, 711-723. [CrossRef] [PubMed]

26. Fellner, C. Ipilimumab (Yervoy) Prolongs Survival in Advanced Melanoma: Serious Side Effects and a Hefty Price Tag may Limit its Use. Pharm. Ther. 2012, 37, 503-511.

27. Greig, S.L. Talimogene Laherparepvec: First Global Approval. Drugs 2016, 76, 147-154. [CrossRef] [PubMed]

28. Liu, B.L.; Robinson, M.; Han, Z.Q.; Branston, R.H.; English, C.; Reay, P.; McGrath, Y.; Thomas, S.K.; Thornton, M.; Bullock, P. ICP34. 5 Deleted Herpes Simplex Virus with Enhanced Oncolytic, Immune Stimulating, and Anti-Tumour Properties. Gene Ther. 2003, 10, 292-303. [CrossRef] [PubMed]

29. Hu, J.C.; Coffin, R.S.; Davis, C.J.; Graham, N.J.; Groves, N.; Guest, P.J.; Harrington, K.J.; James, N.D.; Love, C.A.; McNeish, I.; et al. A Phase I Study of OncoVEXGM-CSF, a Second-Generation Oncolytic Herpes Simplex Virus Expressing Granulocyte Macrophage Colony-Stimulating Factor. Clin. Cancer Res. 2006, 12, 6737-6747. [CrossRef] [PubMed]

30. Senzer, N.N.; Kaufman, H.L.; Amatruda, T.; Nemunaitis, M.; Reid, T.; Daniels, G.; Gonzalez, R.; Glaspy, J.; Whitman, E.; Harrington, K. Phase II Clinical Trial of a Granulocyte-Macrophage Colony-Stimulating Factor-encoding, Second-Generation Oncolytic Herpesvirus in Patients with Unresectable Metastatic Melanoma. J. Clin. Oncol. 2009, 27, 5763-5771. [CrossRef] [PubMed]

31. Kaufman, H.L.; Bines, S.D. OPTIM Trial: A Phase III Trial of an Oncolytic Herpes Virus Encoding GM-CSF for Unresectable Stage III Or IV Melanoma. Future Oncol. 2010, 6, 941-949. [CrossRef] [PubMed]

32. Kaufman, H.L.; Kim, D.W.; DeRaffele, G.; Mitcham, J.; Coffin, R.S.; Kim-Schulze, S. Local and Distant Immunity Induced by Intralesional Vaccination with an Oncolytic Herpes Virus Encoding GM-CSF in Patients with Stage IIIc and IV Melanoma. Ann. Surg. Oncol. 2010, 17, 718-730. [CrossRef] [PubMed]

33. Andtbacka, R.H.I.; Collichio, F.A.; Amatruda, T.; Senzer, N.N.; Chesney, J.; Delman, K.A.; Spitler, L.E.; Puzanov, I.; Doleman, S.; Ye, Y.; et al. OPTiM: A Randomized Phase III Trial of Talimogene Laherparepvec (T-VEC) Versus Subcutaneous (SC) Granulocyte-Macrophage Colony-Stimulating Factor (GM-CSF) for the Treatment (Tx) of Unresected Stage IIIB/C and IV Melanoma. J. Clin. Oncol. 2013, 31, LBA9008. [CrossRef] 
34. Kaufman, H.L.; Andtbacka, R.H.I.; Collichio, F.A.; Amatruda, T.; Senzer, N.N.; Chesney, J.; Delman, K.A.; Spitler, L.E.; Puzanov, I.; Ye, Y.; et al. Primary overall Survival (OS) from OPTiM, a Randomized Phase III Trial of Talimogene Laherparepvec (T-VEC) Versus Subcutaneous (SC) Granulocyte-Macrophage Colony-Stimulating Factor (GM-CSF) for the Treatment (Tx) of Unresected Stage IIIB/C and IV Melanoma. J. Clin. Oncol. 2014, 32, 9008a. [CrossRef]

35. Chesney, J.; Puzanov, I.; Collichio, F.; Singh, P.; Milhem, M.M.; Glaspy, J.; Hamid, O.; Ross, M.; Friedlander, P.; Garbe, C. Randomized, Open-Label Phase II Study Evaluating the Efficacy and Safety of Talimogene Laherparepvec in Combination with Ipilimumab Versus Ipilimumab Alone in Patients with Advanced, Unresectable Melanoma. J. Clin. Oncol. 2018, 36, 1658-1667. [CrossRef] [PubMed]

36. Ribas, A.; Dummer, R.; Puzanov, I.; VanderWalde, A.; Andtbacka, R.H.; Michielin, O.; Olszanski, A.J.; Malvehy, J.; Cebon, J.; Fernandez, E. Oncolytic Virotherapy Promotes Intratumoral T Cell Infiltration and Improves Anti-PD-1 Immunotherapy. Cell 2017, 170, 1109-1119. [CrossRef] [PubMed]

37. Nishiyama, Y.; Kimura, H.; Daikoku, T. Complementary Lethal Invasion of the Central Nervous System by Nonneuroinvasive Herpes Simplex Virus Types 1 and 2. J. Virol. 1991, 65, 4520-4524. [PubMed]

38. Eissa, I.R.; Naoe, Y.; Bustos-Villalobos, I.; Ichinose, T.; Tanaka, M.; Zhiwen, W.; Mukoyama, N.; Morimoto, T.; Miyajima, N.; Hitoki, H. Genomic Signature of the Natural Oncolytic Herpes Simplex Virus HF10 and its Therapeutic Role in Preclinical and Clinical Trials. Front. Oncol. 2017, 7, 149. [CrossRef] [PubMed]

39. Ferris, R.L.; Gross, N.D.; Nemunaitis, J.J.; Andtbacka, R.H.I.; Argiris, A.; Ohr, J.; Vetto, J.T.; Senzer, N.N.; Bedell, C.; Ungerleider, R.S.; et al. Phase I Trial of Intratumoral Therapy using HF10, an Oncolytic HSV-1, Demonstrates Safety in HSV+/HSV- Patients with Refractory and Superficial Cancers. J. Clin. Oncol. 2014, 32, 6082. [CrossRef]

40. Andtbacka, R.; Ross, M.I.; Agarwala, S.S.; Taylor, M.H.; Vetto, J.T.; Neves, R.I.; Daud, A.; Khong, H.T.; Ungerleider, R.S.; Boran, A. Preliminary Results from Phase II Study of Combination Treatment with HF10, a Replication-Competent HSV-1 Oncolytic Virus, and Ipilimumab in Patients with Stage IIIb, IIIc, Or IV Unresectable Or Metastatic Melanoma. J. Clin. Oncol. 2016, 34, 9543. [CrossRef]

41. Alexander, W. ESMO World Congress on Gastrointestinal Cancer and European Post-Chicago Melanoma/Skin Cancer Meeting. PT 2016, 41, 581-586.

42. Shafren, D.R.; Dorahy, D.J.; Ingham, R.A.; Burns, G.F.; Barry, R.D. Coxsackievirus A21 Binds to Decay-Accelerating Factor but Requires Intercellular Adhesion Molecule 1 for Cell Entry. J. Virol. 1997, 71, 4736-4743. [PubMed]

43. Au, G.G.; Lindberg, A.M.; Barry, R.D.; Shafren, D.R. Oncolysis of Vascular Malignant Human Melanoma Tumors by Coxsackievirus A21. Int. J. Oncol. 2005, 26, 1471-1476. [CrossRef] [PubMed]

44. Bradley, S.; Jakes, A.D.; Harrington, K.; Pandha, H.; Melcher, A.; Errington-Mais, F. Applications of Coxsackievirus A21 in Oncology. Oncolytic Virother. 2014, 3, 47-55. [CrossRef] [PubMed]

45. Dharmadhikari, N.; Mehnert, J.; Kaufman, H. Oncolytic Virus Immunotherapy for Melanoma. Curr. Treat. Options Oncol. 2015, 16, 1-15. [CrossRef] [PubMed]

46. Andtbacka, R.H.I.; Kaufman, H.; Daniels, G.A.; Spitler, L.E.; Lutzky, J.; Hallmeyer, S.; Whitman, E.D.; Nemunaitis, J.J.; Zhou, K.; Karpathy, R.; et al. CALM Study: A Phase II Study of Intratumoral Coxsackievirus A21 in Patients with Stage IIIc and Stage IV Malignant Melanoma. J. Clin. Oncol. 2013, 31. [CrossRef]

47. Curti, B.D.; Richards, J.M.; Hallmeyer, S.; Faries, M.B.; Andtbacka, R.H.I.; Daniels, G.A.; Grose, M.; Shafren, D. Activity of a Novel Immunotherapy Combination of Intralesional Coxsackievirus A21 and Systemic Ipilimumab in Advanced Melanoma Patients Previously Treated with Anti-PD1 Blockade Therapy. J. Clin. Oncol. 2017, 35, 3014. [CrossRef]

48. Curti, B.; Richards, J.; Hallmeyer, S.; Faries, M.; Andtbacka, R.; Daniels, G.; Grose, M.; Shafren, D.R. Abstract CT114: The MITCI (Phase 1b) study: A novel immunotherapy combination of intralesional Coxsackievirus A21 and systemic ipilimumab in advanced melanoma patients with or without previous immune checkpoint therapy treatment. Ann. Oncol. 2017, 77, CT114. [CrossRef]

49. Strong, J.E.; Coffey, M.C.; Tang, D.; Sabinin, P.; Lee, P.W. The Molecular Basis of Viral Oncolysis: Usurpation of the Ras Signaling Pathway by Reovirus. EMBO J. 1998, 17, 3351-3362. [CrossRef] [PubMed]

50. Maitra, R.; Ghalib, M.H.; Goel, S. Reovirus: A Targeted Therapeutic-Progress and Potential. Mol. Cancer Res. 2012, 10, 1514-1525. [CrossRef] [PubMed] 
51. Vidal, L.; Pandha, H.S.; Yap, T.A.; White, C.L.; Twigger, K.; Vile, R.G.; Melcher, A.; Coffey, M.; Harrington, K.J.; DeBono, J.S. A Phase I Study of Intravenous Oncolytic Reovirus Type 3 Dearing in Patients with Advanced Cancer. Clin. Cancer Res. 2008, 14, 7127-7137. [CrossRef] [PubMed]

52. Galanis, E.; Markovic, S.N.; Suman, V.J.; Nuovo, G.J.; Vile, R.G.; Kottke, T.J.; Nevala, W.K.; Thompson, M.A.; Lewis, J.E.; Rumilla, K.M.; et al. II Trial of Intravenous Administration of Reolysin $\left({ }^{\circledR}\right)$ (Reovirus Serotype-3-Dearing Strain) in Patients with Metastatic Melanoma. Mol. Ther. 2012, 20, 1998-2003. [CrossRef] [PubMed]

53. Mahalingam, D.; Fountzilas, C.; Moseley, J.; Noronha, N.; Tran, H.; Chakrabarty, R.; Selvaggi, G.; Coffey, M.; Thompson, B.; Sarantopoulos, J. A Phase II Study of REOLYSIN ${ }^{\circledR}$ (Pelareorep) in Combination with Carboplatin and Paclitaxel for Patients with Advanced Malignant Melanoma. Cancer Chemother. Pharmacol. 2017, 79, 697-703. [CrossRef] [PubMed]

54. Mastrangelo, M.J.; Maguire, H.C.; Eisenlohr, L.C.; Laughlin, C.E.; Monken, C.E.; McCue, P.A.; Kovatich, A.J.; Lattime, E.C. Intratumoral Recombinant GM-CSF-Encoding Virus as Gene Therapy in Patients with Cutaneous Melanoma. Cancer Gene Ther. 1999, 6, 409-422. [CrossRef] [PubMed]

55. Hwang, T.; Moon, A.; Burke, J.; Ribas, A.; Stephenson, J.; Breitbach, C.J.; Daneshmand, M.; De Silva, N.; Parato, K.; Diallo, J. A Mechanistic Proof-of-Concept Clinical Trial with JX-594, a Targeted Multi-Mechanistic Oncolytic Poxvirus, in Patients with Metastatic Melanoma. Mol. Ther. 2011, 19, 1913-1922. [CrossRef] [PubMed]

56. Wen, P.Y.; Kesari, S. Malignant Gliomas in Adults. N. Engl. J. Med. 2008, 359, 492-507. [CrossRef] [PubMed]

57. Van Meir, E.G.; Hadjipanayis, C.G.; Norden, A.D.; Shu, H.; Wen, P.Y.; Olson, J.J. Exciting New Advances in Neuro-oncology: The Avenue to a Cure for Malignant Glioma. CA Cancer J. Clin. 2010, 60, 166-193. [CrossRef] [PubMed]

58. Patel, D.M.; Foreman, P.M.; Nabors, L.B.; Riley, K.O.; Gillespie, G.Y.; Markert, J.M. Design of a Phase I Clinical Trial to Evaluate M032, a Genetically Engineered HSV-1 Expressing IL-12, in Patients with Recurrent/Progressive Glioblastoma Multiforme, Anaplastic Astrocytoma, Or Gliosarcoma. Hum. Gene Ther. Clin. Dev. 2016, 27, 69-78. [CrossRef] [PubMed]

59. MacLean, A.R.; Ul-Fareed, M.; Robertson, L.; Harland, J.; Brown, S.M. Herpes Simplex Virus Type 1 Deletion Variants 1714 and 1716 Pinpoint Neurovirulence-Related Sequences in Glasgow Strain 17+ between Immediate Early Gene 1 and the 'a' Sequence. J. General Virol. 1991, 72, 631-639. [CrossRef] [PubMed]

60. Rampling, R.; Cruickshank, G.; Papanastassiou, V.; Nicoll, J.; Hadley, D.; Brennan, D.A.; Petty, R.; MacLean, A.; Harland, J.; McKie, E. Toxicity Evaluation of Replication-Competent Herpes Simplex Virus (ICP 34.5 Null Mutant 1716) in Patients with Recurrent Malignant Glioma. Gene Ther. 2000, 7, 859-866. [CrossRef] [PubMed]

61. Papanastassiou, V.; Rampling, R.; Fraser, M.; Petty, R.; Hadley, D.; Nicoll, J.; Harland, J.; Mabbs, R.; Brown, M. The Potential for Efficacy of the Modified (ICP 34.5-) Herpes Simplex Virus HSV1716 Following Intratumoural Injection into Human Malignant Glioma: A Proof of Principle Study. Gene Ther. 2002, 9, 398-406. [CrossRef] [PubMed]

62. Harrow, S.; Papanastassiou, V.; Harland, J.; Mabbs, R.; Petty, R.; Fraser, M.; Hadley, D.; Patterson, J.; Brown, S.M.; Rampling, R. HSV1716 Injection into the Brain Adjacent to Tumour Following Surgical Resection of High-Grade Glioma: Safety Data and Long-Term Survival. Gene Ther. 2004, 11, 1648-1658. [CrossRef] [PubMed]

63. Mineta, T.; Rabkin, S.D.; Yazaki, T.; Hunter, W.D.; Martuza, R.L. Attenuated Multi-mutated Herpes Simplex Virus-1 for the Treatment of Malignant Gliomas. Nat. Med. 1995, 1, 938-943. [CrossRef] [PubMed]

64. Markert, J.M.; Medlock, M.D.; Rabkin, S.D.; Gillespie, G.Y.; Todo, T.; Hunter, W.D.; Palmer, C.A.; Feigenbaum, F.; Tornatore, C.; Tufaro, F.; et al. Conditionally Replicating Herpes Simplex Virus Mutant, G207 for the Treatment of Malignant Glioma: Results of a Phase I Trial. Gene Ther. 2000, 7, 867-874. [CrossRef] [PubMed]

65. Markert, J.M.; Liechty, P.G.; Wang, W.; Gaston, S.; Braz, E.; Karrasch, M.; Nabors, L.B.; Markiewicz, M.; Lakeman, A.D.; Palmer, C.A.; et al. Phase Ib Trial of Mutant Herpes Simplex Virus G207 Inoculated Pre-and Post-Tumor Resection for Recurrent GBM. Mol. Ther. 2009, 17, 199-207. [CrossRef] [PubMed]

66. Aghi, M.K.; Chiocca, E.A. Phase Ib Trial of Oncolytic Herpes Virus G207 shows Safety of Multiple Injections and Documents Viral Replication. Mol. Ther. 2009, 17, 8-9. [CrossRef] [PubMed] 
67. Markert, J.M.; Razdan, S.N.; Kuo, H.; Cantor, A.; Knoll, A.; Karrasch, M.; Nabors, L.B.; Markiewicz, M.; Agee, B.S.; Coleman, J.M.; Lakeman, A.D.; et al. A Phase 1 Trial of Oncolytic HSV-1, G207, Given in Combination with Radiation for Recurrent GBM Demonstrates Safety and Radiographic Responses. Mol. Ther. 2014, 22, 1048-1055. [CrossRef] [PubMed]

68. Todo, T.; Martuza, R.L.; Rabkin, S.D.; Johnson, P.A. Oncolytic Herpes Simplex Virus Vector with Enhanced MHC Class I Presentation and Tumor Cell Killing. Proc. Natl. Acad. Sci. USA 2001, 98, 6396-6401. [CrossRef] [PubMed]

69. Fukuhara, H.; Ino, Y.; Todo, T. Oncolytic Virus Therapy: A New Era of Cancer Treatment at Dawn. Cancer Sci. 2016, 107, 1373-1379. [CrossRef] [PubMed]

70. Chiocca, E.A.; Abbed, K.M.; Tatter, S.; Louis, D.N.; Hochberg, F.H.; Barker, F.; Kracher, J.; Grossman, S.A.; Fisher, J.D.; Carson, K.; et al. A Phase I Open-Label, Dose-Escalation, Multi-Institutional Trial of Injection with an E1B-Attenuated Adenovirus, ONYX-015, into the Peritumoral Region of Recurrent Malignant Gliomas, in the Adjuvant Setting. Mol. Ther. 2004, 10, 958-966. [CrossRef] [PubMed]

71. Lang, F.F.; Conrad, C.; Gomez-Manzano, C.; Yung, W.A.; Sawaya, R.; Weinberg, J.S.; Prabhu, S.S.; Rao, G.; Fuller, G.N.; Aldape, K.D. Phase I Study of DNX-2401 (Delta-24-RGD) Oncolytic Adenovirus: Replication and Immunotherapeutic Effects in Recurrent Malignant Glioma. J. Clin. Oncol. 2018, 36, 1419-1427. [CrossRef] [PubMed]

72. Lang, F.F.; Conrad, C.; Gomez-Manzano, C.; Tufaro, F.; Yung, W.; Sawaya, R.; Weinberg, J.; Prabhu, S.; Fuller, G.; Aldape, K. First-in-Human Phase I Clinical Trial of Oncolytic Delta-24-Rgd (Dnx-2401) with Biological Endpoints: Implications for Viro-Immunotherapy. Neuro. Oncol. 2014, 16, iii39. [CrossRef]

73. Forsyth, P.; Roldn, G.; George, D.; Wallace, C.; Palmer, C.A.; Morris, D.; Cairncross, G.; Matthews, M.V.; Markert, J.; Gillespie, Y. A Phase I Trial of Intratumoral Administration of Reovirus in Patients with Histologically Confirmed Recurrent Malignant Gliomas. Mol. Ther. 2008, 16, 627-632. [CrossRef] [PubMed]

74. Kicielinski, K.P.; Chiocca, E.A.; John, S.Y.; Gill, G.M.; Coffey, M.; Markert, J.M. Phase 1 Clinical Trial of Intratumoral Reovirus Infusion for the Treatment of Recurrent Malignant Gliomas in Adults. Mol. Ther. 2014, 22, 1056-1062. [CrossRef] [PubMed]

75. Freeman, A.I.; Zakay-Rones, Z.; Gomori, J.M.; Linetsky, E.; Rasooly, L.; Greenbaum, E.; Rozenman-Yair, S.; Panet, A.; Libson, E.; Irving, C.S. Phase I/II Trial of Intravenous NDV-HUJ Oncolytic Virus in Recurrent Glioblastoma Multiforme. Mol. Ther. 2006, 13, 221-228. [CrossRef] [PubMed]

76. Geletneky, K.; Hajda, J.; Angelova, A.L.; Leuchs, B.; Capper, D.; Bartsch, A.J.; Neumann, J.; Schöning, T.; Hüsing, J.; Beelte, B.; et al. Oncolytic H-1 Parvovirus shows Safety and Signs of Immunogenic Activity in a First Phase I/IIa Glioblastoma Trial. Mol. Ther. 2017, 25, 2620-2634. [CrossRef] [PubMed]

77. Desjardins, A.; Gromeier, M.; Herndon, J.E.; Beaubier, N.; Bolognesi, D.P.; Friedman, A.H.; Friedman, H.S.; McSherry, F.; Muscat, A.M.; Nair, S. Recurrent Glioblastoma Treated with Recombinant Poliovirus. N. Engl. J. Med. 2018, 379, 150-161. [CrossRef] [PubMed]

78. Howlader, N.; Noone, A.M.; Krapcho, M.; Miller, D.; Bishop, K.; Altekruse, S.F.; Kosary, C.L.; Yu, M.; Ruhl, J.; Tatalovich, Z.; et al. (Eds.) SEER Cancer Statistics Review, 1975-2013. National Cancer Institute: Bethesda, MD, USA. Available online: https:/ / seer.cancer.gov/archive/csr/1975_2013/, based on November 2015 SEER data submission, posted to the SEER web site (accessed on 12 April 2016).

79. Hidalgo, M.; Cascinu, S.; Kleeff, J.; Labianca, R.; Löhr, J.M.; Neoptolemos, J.; Real, F.X.; Van Laethem, J.; Heinemann, V. Addressing the Challenges of Pancreatic Cancer: Future Directions for Improving Outcomes. Pancreatology 2015, 15, 8-18. [CrossRef] [PubMed]

80. Vincent, A.; Herman, J.; Schulick, R.; Hruban, R.H.; Goggins, M. Pancreatic Cancer. Lancet 2011, 378, 607-620. [CrossRef]

81. Falasca, M.; Kim, M.; Casari, I. Pancreatic Cancer: Current Research and Future Directions. Biochim. Biophys. Acta 2016, 1865, 123-132. [CrossRef] [PubMed]

82. Le, D.T.; Uram, J.N.; Wang, H.; Bartlett, B.R.; Kemberling, H.; Eyring, A.D.; Skora, A.D.; Luber, B.S.; Azad, N.S.; Laheru, D. PD-1 Blockade in Tumors with Mismatch-Repair Deficiency. N. Engl. J. Med. 2015, 372, 2509-2520. [CrossRef] [PubMed]

83. Beatty, G.L.; Gladney, W.L. Immune Escape Mechanisms as a Guide for Cancer Immunotherapy. Clin. Cancer Res. 2015, 21, 687-692. [CrossRef] [PubMed]

84. Skelton, R.A.; Javed, A.; Zheng, L.; He, J. Overcoming the Resistance of Pancreatic Cancer to Immune Checkpoint Inhibitors. J. Surg. Oncol. 2017, 116, 55-62. [CrossRef] [PubMed] 
85. Al-Batran, S.; Geissler, M.; Seufferlein, T.; Oettle, H. Nab-Paclitaxel for Metastatic Pancreatic Cancer: Clinical Outcomes and Potential Mechanisms of Action. Oncol. Res. Treat. 2014, 37, 128-134. [CrossRef] [PubMed]

86. Wang, Y.; Camateros, P.; Cheung, W.Y. A Real-World Comparison of FOLFIRINOX, Gemcitabine Plus Nab-Paclitaxel, and Gemcitabine in Advanced Pancreatic Cancers. J. Gastrointest. Cancer 2017, 1-7. [CrossRef] [PubMed]

87. Johansson, H.; Andersson, R.; Bauden, M.; Hammes, S.; Holdenrieder, S.; Ansari, D. Immune Checkpoint Therapy for Pancreatic Cancer. World J. Gastroenterol. 2016, 22, 9457-9476. [CrossRef] [PubMed]

88. Cheng, P.; Wechman, S.L.; McMasters, K.M.; Zhou, H.S. Oncolytic Replication of E1B-Deleted Adenoviruses. Viruses 2015, 7, 5767-5779. [CrossRef] [PubMed]

89. Mulvihill, S.; Warren, R.; Venook, A.; Adler, A.; Randlev, B.; Heise, C.; Kirn, D. Safety and Feasibility of Injection with an E1B-55 kDa Gene-Deleted, Replication-Selective Adenovirus (ONYX-015) into Primary Carcinomas of the Pancreas: A Phase I Trial. Gene Ther. 2001, 8, 308-315. [CrossRef] [PubMed]

90. Hecht, J.R.; Bedford, R.; Abbruzzese, J.L.; Lahoti, S.; Reid, T.R.; Soetikno, R.M.; Kirn, D.H.; Freeman, S.M. A Phase I/II Trial of Intratumoral Endoscopic Ultrasound Injection of ONYX-015 with Intravenous Gemcitabine in Unresectable Pancreatic Carcinoma. Clin. Cancer Res. 2003, 9, 555-561. [PubMed]

91. Nakao, A.; Kasuya, H.; Sahin, T.T.; Nomura, N.; Kanzaki, A.; Misawa, M.; Shirota, T.; Yamada, S.; Fujii, T.; Sugimoto, H.; et al. A Phase I Dose-Escalation Clinical Trial of Intraoperative Direct Intratumoral Injection of HF10 Oncolytic Virus in Non-Resectable Patients with Advanced Pancreatic Cancer. Cancer Gene Ther. 2011, 18, 167-175. [CrossRef] [PubMed]

92. Kasuya, H.; Kodera, Y.; Nakao, A.; Yamamura, K.; Gewen, T.; Zhiwen, W.; Hotta, Y.; Yamada, S.; Fujii, T.; Fukuda, S.; et al. Phase I Dose-Escalation Clinical Trial of HF10 Oncolytic Herpes Virus in 17 Japanese Patients with Advanced Cancer. Hepatogastroenterology 2014, 61, 599-605. [PubMed]

93. Chang, K.J.; Senzer, N.N.; Binmoeller, K.; Goldsweig, H.; Coffin, R. Phase I dose-escalation study of talimogene laherparepvec (T-VEC) for advanced pancreatic cancer (ca). J. Clin. Oncol. 2012, 30, e14546.

94. Noonan, A.M.; Farren, M.R.; Geyer, S.M.; Huang, Y.; Tahiri, S.; Ahn, D.; Mikhail, S.; Ciombor, K.K.; Pant, S.; Aparo, S. Randomized Phase 2 Trial of the Oncolytic Virus Pelareorep (Reolysin) in Upfront Treatment of Metastatic Pancreatic Adenocarcinoma. Mol. Ther. 2016, 24, 1150-1158. [CrossRef] [PubMed]

95. Mahalingam, D.; Patel, S.; Nuovo, G.; Gill, G.; Selvaggi, G.; Coffey, M.; Nawrocki, S.T. The Combination of Intravenous Reolysin and Gemcitabine Induces Reovirus Replication and Endoplasmic Reticular Stress in a Patient with KRAS-Activated Pancreatic Cancer. BMC Cancer 2015, 15, 513. [CrossRef] [PubMed]

96. Mahalingam, D.; Goel, S.; Aparo, S.; Patel Arora, S.; Noronha, N.; Tran, H.; Chakrabarty, R.; Selvaggi, G.; Gutierrez, A.; Coffey, M. A Phase II Study of Pelareorep (REOLYSIN ${ }^{\circledR}$ ) in Combination with Gemcitabine for Patients with Advanced Pancreatic Adenocarcinoma. Cancers 2018, 10, 160. [CrossRef] [PubMed]

97. Siegel, R.L.; Miller, K.D.; Jemal, A. Cancer Statistics, 2016. CA Cancer J. Clin. 2016, 66, 7-30. [CrossRef] [PubMed]

98. Nakao, A.; Kimata, H.; Imai, T.; Kikumori, T.; Teshigahara, O.; Nagasaka, T.; Goshima, F.; Nishiyama, Y. Intratumoral Injection of Herpes Simplex Virus HF10 in Recurrent Breast Cancer. Ann. Oncol. 2004, 15, 988-989. [CrossRef] [PubMed]

99. Kimata, H.; Imai, T.; Kikumori, T.; Teshigahara, O.; Nagasaka, T.; Goshima, F.; Nishiyama, Y.; Nakao, A. Pilot Study of Oncolytic Viral Therapy using Mutant Herpes Simplex Virus (HF10) Against Recurrent Metastatic Breast Cancer. Ann. Surg. Oncol. 2006, 13, 1078-1084. [CrossRef] [PubMed]

100. Nemunaitis, J.; Senzer, N.; Sarmiento, S.; Zhang, Y.; Arzaga, R.; Sands, B.; Maples, P.; Tong, A.W. A Phase I Trial of Intravenous Infusion of ONYX-015 and Enbrel in Solid Tumor Patients. Cancer Gene Ther. 2007, 14, 885-893. [CrossRef] [PubMed]

101. Nokisalmi, P.; Pesonen, S.; Escutenaire, S.; Särkioja, M.; Raki, M.; Cerullo, V.; Laasonen, L.; Alemany, R.; Rojas, J.; Cascallo, M.; et al. Oncolytic Adenovirus ICOVIR-7 in Patients with Advanced and Refractory Solid Tumors. Clin. Cancer Res. 2010, 16, 3035-3043. [CrossRef] [PubMed]

102. Zeh, H.J.; Downs-Canner, S.; McCart, J.A.; Guo, Z.S.; Rao, U.N.; Ramalingam, L.; Thorne, S.H.; Jones, H.L.; Kalinski, P.; Wieckowski, E.; et al. First-in-Man Study of Western Reserve Strain Oncolytic Vaccinia Virus: Safety, Systemic Spread, and Antitumor Activity. Mol. Ther. 2015, 23, 202-214. [CrossRef] [PubMed]

103. Laurie, S.A.; Bell, J.C.; Atkins, H.L.; Roach, J.; Bamat, M.K.; O’Neil, J.D.; Roberts, M.S.; Groene, W.S.; Lorence, R.M. A Phase 1 Clinical Study of Intravenous Administration of PV701, an Oncolytic Virus, using Two-Step Desensitization. Clin. Cancer Res. 2006, 12, 2555-2562. [CrossRef] [PubMed] 
104. Gollamudi, R.; Ghalib, M.H.; Desai, K.K.; Chaudhary, I.; Wong, B.; Einstein, M.; Coffey, M.; Gill, G.M.; Mettinger, K.; Mariadason, J.M. Intravenous Administration of Reolysin ${ }^{\circledR}$, a Live Replication Competent RNA Virus is Safe in Patients with Advanced Solid Tumors. Invest. New Drugs 2010, 28, 641-649. [CrossRef] [PubMed]

105. Bernstein, V.; Ellard, S.L.; Dent, S.F.; Tu, D.; Mates, M.; Dhesy-Thind, S.K.; Panasci, L.; Gelmon, K.A.; Salim, M.; Song, X. A Randomized Phase II Study of Weekly Paclitaxel with or without Pelareorep in Patients with Metastatic Breast Cancer: Final Analysis of Canadian Cancer Trials Group IND. 213. Breast Cancer Res. Treat. 2018, 167, 485-493. [CrossRef] [PubMed] 